\title{
Cannabidiol: A Potential New Alternative for the Treatment of Anxiety, Depression, and Psychotic Disorders
}

\author{
María S. García-Gutiérrez ${ }^{1,2}$, Francisco Navarrete ${ }^{1,2}$, Ani Gasparyan 1,2 (D), \\ Amaya Austrich-Olivares ${ }^{1}$, Francisco Sala ${ }^{1}$ and Jorge Manzanares ${ }^{1,2, *}$ \\ 1 Neurosciences Institute, University Miguel Hernández-CSIC, Avda de Ramón y Cajal s/n, \\ San Juan de Alicante, 03550 Alicante, Spain; maria.ggutierrez@goumh.umh.es (M.S.G.-G.); \\ fnavarrete@umh.es (F.N.); agasparyan@umh.es (A.G.); aaustrich@umh.es (A.A.-O.); fsala@umh.es (F.S.) \\ 2 Subject Area Network of Cooperative Health Research (RETICS), Network for Addiction Disorders, \\ Health Institute Carlos III, MICINN and FEDER, 28029 Madrid, Spain \\ * Correspondence: jmanzanares@umh.es; Tel.: +34-96-591-9248
}

Received: 18 September 2020; Accepted: 18 November 2020; Published: 19 November 2020

\begin{abstract}
The potential therapeutic use of some Cannabis sativa plant compounds has been attracting great interest, especially for managing neuropsychiatric disorders due to the relative lack of efficacy of the current treatments. Numerous studies have been carried out using the main phytocannabinoids, tetrahydrocannabinol (THC) and cannabidiol (CBD). CBD displays an interesting pharmacological profile without the potential for becoming a drug of abuse, unlike THC. In this review, we focused on the anxiolytic, antidepressant, and antipsychotic effects of CBD found in animal and human studies. In rodents, results suggest that the effects of CBD depend on the dose, the strain, the administration time course (acute vs. chronic), and the route of administration. In addition, certain key targets have been related with these $\mathrm{CBD}$ pharmacological actions, including cannabinoid receptors $\left(\mathrm{CB}_{1} \mathrm{r}\right.$ and $\left.\mathrm{CB}_{2} \mathrm{r}\right), 5-\mathrm{HT}_{1 \mathrm{~A}}$ receptor and neurogenesis factors. Preliminary clinical trials also support the efficacy of $\mathrm{CBD}$ as an anxiolytic, antipsychotic, and antidepressant, and more importantly, a positive risk-benefit profile. These promising results support the development of large-scale studies to further evaluate $\mathrm{CBD}$ as a potential new drug for the treatment of these psychiatric disorders.
\end{abstract}

Keywords: cannabidiol; depressive disorders; PTSD; anxiety disorders; schizophrenia; clinical trials; animal studies

\section{Introduction}

Mental health is currently a major public health challenge worldwide. Approximately one in four people experience some type of mental health problem at least once in their lives. Using disability adjusted life years (DALYs-years lost to ill health and premature death) as the basic measure of impact, mental health problems accounted for $19.5 \%$ of the global burden of disease [1]. Depression, alcohol use disorders, and suicide rank in the top 20 causes of DALYs lost due to all diseases at all ages [2]. In many countries, neuropsychiatric disorders account for $35 \%$ to $45 \%$ of absenteeism at work and are often associated with human rights violations, discrimination and stigma [3].

One major consequence of mental disorders is suicide. Major depressive disorder (MDD), bipolar disorder, schizophrenia (SCZ), and alcohol-use disorders (AUD) are the main risk factors for suicide [4-6], which takes approximately 800,000 lives each year. Suicide is the second leading cause of death in people aged 15 to 29 years, and the first in men under 40 years [7].

Limited access to mental health services and to pharmacological and psychotherapeutic treatments, especially in low- and middle-income countries, is a huge problem for these patients. Furthermore, 
their reluctance to seek help due to fear of being rejected by their family, friends, and community continues to be an obstacle to achieving the highest standard of mental health and well-being.

In contrast to other human diseases, neuropsychiatric disorders are not diagnosed on the basis of objective biological measures, but rather a list of symptoms, according to the Diagnostic and Statistical Manual of Mental Disorders, Fifth Edition, (DSM-V) or to the International Classification of Diseases, Tenth revision (ICD-10). These procedures result in a high degree of heterogeneity among patients diagnosed with the same psychiatric disease [8]. In part, this is because different psychiatric disorders share common symptoms and display high comorbidity, making it difficult to reach an accurate diagnosis. Together with these problems, current pharmacological and psychotherapeutic treatment options present low efficacy, particularly in medium- to high-severity cases [9-11]. The limited knowledge of the neurobiological mechanisms underlying neuropsychiatric diseases makes the pharmacological treatment unspecific, so the same drug groups are used for different mental disorders.

Efforts have been made to characterize the etiopathogenesis of mental disorders and to identify potential biomarkers to guide diagnosis, prognosis and the development of potential new drugs. In this respect, translational research and the advent of new technological approaches, such as neuroimaging and "omics" techniques are driving advances [12].

Thanks to these types of research, it has been possible to identify new neurotransmission systems involved in psychiatric disorders, such as the glutamatergic [13-15], GABAergic [16-18], and endocannabinoid systems (ECS) [19-22]. Some of these findings have led to the development and marketing of drugs with new mechanisms of action, such as esketamine, a non-competitive $\mathrm{N}$-methyl-D-aspartate (NMDA) receptor antagonist, approved as therapy for treatment-resistant depression in adults in the USA and Europe [23-25]. Another potential drug attracting attention is cannabidiol, one of the major compounds present in the plant Cannabis sativa [26]. Animal models have shown that cannabidiol (CBD) displays anxiolytic, antidepressant, antipsychotic, antiepileptic and neuroprotective properties, suggesting its potential therapeutic use for several psychiatric, neurological and drug-use disorders. CBD was approved in 2018 by the U.S. Food and Drug Administration (FDA) after it was shown to be effective and safe for treating seizures associated with Lennox-Gastaut syndrome or Dravet syndrome in patients aged two years and older. This has accelerated research into its use for additional disorders. In this review, we summarize the main results provided by animal models and preliminary clinical trials conducted to date on the efficacy of CBD for treating anxiety, depressive disorders, post-traumatic stress disorder (PTSD), and SCZ. The hypothesized mechanisms of action by which CBD potentially produces its effects on these disorders are also explored. Although our results support the efficacy and safety of CBD, large-scale clinical studies are required before its final approval for human clinical use in these psychiatric disorders.

\section{Introduction to the Phytocannabinoid Cannabidiol: Chemical Structure, Pharmacokinetics and Pharmacodynamics Profile}

Over the last decades, several investigations have focused on characterizing the biological and molecular bases involved in the medical properties of the plant Cannabis sativa. To date, approximately 120 cannabinoids have been identified and classified into 11 groups based on their chemical structure: $\Delta^{9}$-trans-tetrahydrocannabinol $\left(\Delta^{9}\right.$-THC), cannabigerol, cannabicromeno, cannabidiol (CBD), cannabinodiol, cannabielsoin, cannabicyclol, cannabinol, cannabitriol, and a last group in which several cannabinoids with different chemical structure are included [27]. The main compound present in the plant is $\Delta^{9}$-THC, characterized by Gaoni and Mechoulam in 1964, responsible for the reinforcing properties of cannabis [28]. CBD is the following majority compound isolated for the first time by Adams and cols. in 1940 [29], although its chemical structure was not fully characterized until 1963 [30]. 


\subsection{Overview of CBD Chemical Structure}

CBD has a chemical structure similar to $\Delta^{9}$-THC; however, both differ on the spatial conformation, fact that helps to explain the differences observed in relation to their physiopharmacological properties. $\Delta^{9}$-THC presents a planar structure that allows binding to the $\mathrm{rCB}_{1}$. In contrast, $\mathrm{CBD}$ has a slightly angular structure that produces a steric hindrance that hampers its ability to bind to this receptor [31]. As consequence, CBD displays 100 times less affinity for $\mathrm{rCB}_{1}$ than $\Delta^{9}$-THC [32]. This may justify the absence of reinforcing properties of $\mathrm{CBD}$ as opposed to $\Delta^{9}-\mathrm{THC}$ [31]. In fact, data achieve to date show that CBD did not induce euphoria or intoxication in healthy volunteers [33-35]. Animal studies suggested that CBD may not present reinforcing properties since it did not exhibit drug abuse potential in the conditioned place preference, spontaneous withdrawal and oral self-administration, common animal models used to evaluate the abuse potential of drugs [36-38].

\subsection{Overview of CBD Pharmacological Profile}

During the last years, many researchers studied the potential therapeutic utility of CBD in different diseases pointing out its possible antimicrobial, immunosuppressive, antiemetic, anti-resorptive, spasmolytic, antitumor, antifibrotic, anti-inflammatory, and anticonvulsant efficacy [39-42]. Some of these properties were further explored leading to its approval for treating spasticity in multiple sclerosis (Sativex) [43] and more recently for treating seizures associated with Lennox-Gastaut or Dravet syndromes in children [44]. Furthermore, other reports suggest that CBD may be useful for treating neurodegenerative [45-48] and psychiatric disorders [39,49-51]. Both animal and clinical studies pointed out that CBD presents anxiolytic, antidepressant, and antipsychotic properties, this will be further explored in detail in the following sections.

\subsubsection{Pharmacokinetics}

As the majority of phytocannabinoids, CBD presents high liposolubility $\left(\mathrm{K}_{\mathrm{o} / \mathrm{w}}: 6-7\right)$ [52]. The oral administration of CBD presents a poor bioavailability (6-19\%) [53] mainly due to its extensive first-pass metabolism. To increase its oral availability, it is recommended to administer CBD together with food. Other routes of administration such as inhalation or intravenous provide better concentrations and more quickly [53,54]. Table 1 summarizes the main pharmacokinetics properties of CBD.

CBD presents a high distribution ( $\mathrm{Vd}: 32 \mathrm{~L} / \mathrm{kg}$ ) with great accumulation in brain and adipose tissues, also due to its high liposolubility [55-57]. CBD is metabolized in the liver by different mechanisms (including oxidation, $\beta$-oxidation, hydroxylation, glucuronide conjugation and epoxidation) $[53,56,58-60]$ and eliminated in the urine unmetabolized or as a glucuronide derivative [53,59]. There are different CBD metabolites (around 53), some of them under study to determine its potential involvement in some of its actions.

Table 1. Main pharmacokinetics parameters of cannabidiol (CBD).

\begin{tabular}{ccc}
\hline Parameter & Values & References \\
\hline $\mathrm{K}_{\mathrm{o} / \mathrm{w}}$ & $6-7$ & {$[52]$} \\
Oral bioavailability & $6-19 \%$ & {$[53]$} \\
Cmax & $3 \pm 3.1 \mu \mathrm{g} / \mathrm{L}$ & {$[55,56,61]$} \\
$\mathrm{Tmax}$ & $2.8 \pm 1.3 \mathrm{~h}$ & $32 \mathrm{~L} / \mathrm{kg}$ \\
$\mathrm{Vd}$ & $1.4-10.9 \mathrm{~h}$ (oromucosal spray) & \\
& $2-5 \mathrm{~h}$ (oral chronic administration) & {$[55-57]$} \\
$\mathrm{t}_{1 / 2}$ & $24 \mathrm{~h}$ (intravenously) & \\
& $31 \mathrm{~h}$ (smoked) & \\
Plasma clearance rate & $960-1500$ mL/min & {$[53-55]$} \\
\hline
\end{tabular}

$\mathrm{K}_{\mathrm{o} / \mathrm{w}}$ : octanol water partition coefficient; Cmax: maximum concentration; Tmax: maximum time; Vd: volume of distribution; $\mathrm{t}_{1 / 2}$ : half-life. 
Finally, evidences about its safety and tolerability are limited to preclinical and clinical studies. No significant side effects have been described $[62,63]$. Diarrhea, somnolence and decreased appetite are the most commonly side effects reported in the clinical trials performed in children with Lennox-Gastaut syndrome [44].

It is also interesting to highlight that CBD is a potent competitive inhibitor of certain cytochrome P450 isoforms (CYP2C and CYP3A) increasing the risk of drug-interactions when is given together with other drugs metabolized by these enzymes [53,59,60].

\subsubsection{Pharmacodynamics}

CBD has the peculiarity of acting on more than 65 key targets, including the serotonin $1 \mathrm{~A}$ receptor $\left(5-\mathrm{HT}_{1 \mathrm{~A}}\right)$, the cannabinoid-related receptors $\mathrm{G}$ protein-coupled receptor 55 (GPR55), transient receptor potential vanilloid 1 (TRPV1), type 1 equilibrative nucleoside transporter (ETN1), fatty acid-binding protein (FABP), nuclear factor erythroid 2-related factor 2 (NRF2), voltage-activated T-type calcium channels, adenosine and glycine receptors, $\mathrm{mu}$ and delta opioid receptors, and voltage-dependent anion channel 1 (VDAC1), among others [64].

The first in vitro studies revealed that CBD, at sub-micromolar concentrations, acts as an antagonist of $\mathrm{CB}_{1} \mathrm{r}$ and as an inverse agonist of $\mathrm{CB}_{2} \mathrm{r}$ [65]. However, subsequent in vivo studies showed that CBD presents low affinity for both receptors [66-68]. CBD seems to act more like a negative allosteric modulator of $\mathrm{CB}_{1} \mathrm{r}$, modifying the power and efficiency with which endogenous cannabinoids activate the receptor [69]. In contrast, some studies indicated that CBD inhibits reuptake of anandamide (AEA) and its metabolization by the fatty acid amide hydrolase (FAAH), increasing the endogenous cannabinoid tone, a mechanism suggested by which CBD may indirectly activates $\mathrm{CB}_{1} \mathrm{r}$ [70].

In the case of $\mathrm{CB}_{2} \mathrm{r}, \mathrm{CBD}$ acts as an inverse agonist but only at very high concentrations [71]. Moreover, CBD also acts as an antagonist of cannabinoid-related receptors as the GPR55 considered one of the main targets by which CBD exerts its properties [72-74].

Additional targets, including key elements of the opioidergic, dopaminergic, glutamatergic and serotonergic systems have been associated with the actions of CBD. CBD inhibits the reuptake of dopamine and glutamate in vitro [75,76]. Besides, CBD is an allosteric modulator of mu and delta opioid receptors $[77,78]$ and a partial agonist of dopamine $\mathrm{D}_{2}$ receptors, reinforcing its potential as an antipsychotic $[79,80]$.

Interestingly, additional in vitro and in vivo studies revealed that CBD induces physiological responses trough $5-\mathrm{HT}_{1 \mathrm{~A}}$ receptors [27,81], a serotoninergic key target involved in anxiety and depression.

\section{Role of CBD on Anxiety and Depressive Disorders: Animal and Human Studies}

\subsection{Current Scenario}

Today, over 260 million people worldwide suffer from anxiety and mood disorders, affecting an estimated $25 \%$ of the European population. Apart from its high incidence, these psychiatric disorders present high rates of prevalence, leading to a substantial reduction in the quality of life and disruptions in work/school performance, family/social life and common daily activities. In fact, anxiety and mood disorders are the main mental health causes for years lived with disability (YLD), standing at 302 YLD and 850 YLD per 100,000 inhabitants in Europe, respectively [82]. Consequently, both psychiatric disorders entail high economic costs, of around EUR 170 billion per year in Europe.

According to the DSM-V, anxiety disorders are classified into generalized anxiety disorder, panic disorder, specific or social phobias and social anxiety disorder (SAD) [83]. All types share common symptoms, including feelings of uneasiness, panic and fear; sleep problems; not being able to stay calm; being cold and/or sweaty; shortness of breath; heart palpitations; dry mouth; nausea; and avoidance of situations. Depressive disorders present high complexity and may be classified into disruptive mood dysregulation disorder (MDD), persistent depressive disorder (dysthymia), 
premenstrual dysphoric disorder, substance/medication-induced depressive disorder, associated with another medical condition, other specified depressive disorder and unspecified depressive disorder. Patients suffering from depressive disorders experience emotional, cognitive, physical and behavioral alterations including sadness, anxiety, guilt, irritability, impaired memory, thoughts of death and suicide, loss of motivation, disturbed sleep or appetite, tiredness, neglect of responsibilities, changes in personal appearance, and withdrawal from others [84]. The severity of depressive disorders, assessed by clinician-administered depression assessment scales, such as the Hamilton Depression Rating Scale, varies from one patient to another, with moderate-severe cases presenting worse prognosis [85]. Anxiety and depressive disorders are strongly associated with high rates of comorbidity (around $50 \%$ ) [86], which can reach $90 \%$ in psychiatric patients [87,88]. Comorbidity worsens clinical management and consequently, prognosis; it increases resistance to treatment and recurrence, and it dramatically heightens the risk of suicide.

From a pharmacological point of view, anxiolytics and antidepressants are used in the clinical management of both mental disorders. For instance, benzodiazepines, the most common anxiolytic drug, is useful at the beginning of pharmacological treatment of depressive disorders [89]. Similarly, buspirone (a serotonin $5-\mathrm{HT}_{1 \mathrm{~A}}$ receptor agonist) is an anxiolytic for treating depressive disorders [90]. Antidepressants, especially selective serotonin reuptake inhibitors, are the most commonly used first-line treatment for anxiety disorders [91]. Although neurochemical alterations underlying anxiety and depression still remain to be elucidated, the beneficial effects found during the co-administration of both types of drugs suggest the involvement of shared neurobiological pathways.

Despite the available pharmacological treatment options, efficacy is limited, especially for preventing relapse and recurrence [92]. For example, one in three patients diagnosed with MDD develops resistance to antidepressant drugs. More importantly, current pharmacological treatments do not improve the cognitive dysfunctions associated with this mental disorder, even when combined with psychotherapy $[93,94]$. Conversely, the side effects of these medications, such as weight gain, loss of sexual desire and others, affect the risk-benefit ratio. Therefore, it is necessary to find new pharmacological alternatives to improve treatment outcomes for such psychiatric disorders without the burden of disabling side effects. In this respect, published animal and clinical studies, whose main results are detailed below, provide information supporting the anxiolytic and antidepressant properties of CBD.

\subsection{Results from Animal Studies}

The potential anxiolytic and antidepressant properties of CBD have been examined in several animal models since the late 1970s. Although preliminary findings were contradictory $[95,96]$, subsequent dose-response studies showed that CBD induced an anxiolytic-like effect, which followed an inverted U-shaped curve, resulting effective at intermediate doses but not at low or high doses [97-99]. CBD also attenuated physiological and behavioral responses to stressful situations, reducing restraint stress along with cardiovascular and anxiogenic-like responses [100] by blocking the activation of the hypothalamus-pituitary-adrenal (HPA) axis [101] and activating the 5- $\mathrm{HT}_{1 \mathrm{~A}}$ receptor [100]. Additional results from studies carried out using the Vogel-conflict and the marble-burying tests showed that CBD reduced anxiety- and compulsive-like behaviors, respectively $[49,102,103]$ (Table 2). Curiously, cannabinoid $\mathrm{CB}_{1}$ receptor $\left(\mathrm{CB}_{1} \mathrm{r}\right)$, but not $5-\mathrm{HT}_{1 \mathrm{~A}}$ receptor, appears to mediate such effects [104]. The administration of CBD also abolished anxiety-like behavior, hyperthermia and hyperlocomotion induced by tetrahydrocannabinol (THC), modifying c-Fos expression in brain regions (medial preoptic nucleus and lateral periaqueductal gray) [105]. In contrast, CBD failed to modify anxiety induced by repeated administration of THC [106]. 
Table 2. Summary of cannabidiol studies on animal models of anxiety and depression.

\begin{tabular}{|c|c|c|c|}
\hline Strain & Doses and Route of Administration & Effect and Test & Reference \\
\hline \multirow{23}{*}{ Wistar rats } & $1 \mathrm{mg} / \mathrm{kg}$; i.p.; acute & Anxiolytic/SI & [99] \\
\hline & $2.5,5,10.0 \mathrm{mg} / \mathrm{kg}$; i.p.; acute & Anxiolytic/EPM & [97] \\
\hline & 7-30 mg/kg; i.p.; acute & Antidepressant/FST & [107] \\
\hline & 5 and $15 \mathrm{mg} / \mathrm{kg}$, i.p.; acute & No effect/SI & [99] \\
\hline & 1,10,20 mg/kg; i.p.; acute & Anxiolytic/restraint stress & [100] \\
\hline & $\begin{array}{c}10 \mathrm{mg} / \mathrm{kg} \text {; i.p.; acute } \\
10 \mathrm{mg} / \mathrm{kg} \text {; i.p.; } 28 \text { days }\end{array}$ & $\begin{array}{c}\text { Anxiolytic/THC-induced conditioned } \\
\text { emotional responses } \\
\text { Anxiolytic/VCT } \\
\text { Anxiolytic/CFC } \\
\text { Antidepressant/CMS }\end{array}$ & {$[96,102,108]$} \\
\hline & 20 mg/kg; i.p.; acute & No effect/EPM & [97] \\
\hline & 3-30 mg/kg; i.p.; acute & $\downarrow$ freezing behavior/CFC & [109] \\
\hline & $30 \mathrm{mg} / \mathrm{kg}$; p.o.; acute & Antidepressant/FST & [110] \\
\hline & $30 \mathrm{mg} / \mathrm{kg}$; i.p.; acute and chronic & Antidepressant/FST & [111] \\
\hline & 100 mg/kg; i.p.; acute & No effect/GSP & [95] \\
\hline & $30 \mathrm{nmol} / \mu \mathrm{L} ; \mathrm{dlPAG}$; acute & Anxiolytic/EPM and VCT & [112] \\
\hline & 30 and $60 \mathrm{nmol} / \mu \mathrm{L} ; \mathrm{PAG}$; acute & Anxiolytic/ETMPanicolytic/ES dPAG & [113] \\
\hline & 30 and $60 \mathrm{nmol} / \mu \mathrm{L}$; BNST; acute & Anxiolytic/restraint stress & [114] \\
\hline & $30 \mathrm{nmol} / \mu \mathrm{L}$; intracisternal; acute & Anxiolytic/restraint stress & [115] \\
\hline & $30 \mathrm{nmol} / \mu \mathrm{L} ; \mathrm{PL} ;$ acute & Anxiolytic/EPM & [116] \\
\hline & $2 \mu \mathrm{g} / \mu \mathrm{L} ; \mathrm{icv}$ and $\mathrm{mPFC} ;$ acute & $\downarrow$ freezing behavior/CFC & [117] \\
\hline & 15 or $30 \mathrm{nmol} / \mu \mathrm{L}$; IL-PFC; acute & $\uparrow$ freezing behavior/CFC & [118] \\
\hline & $30 \mathrm{nmol} / \mu \mathrm{L} ; \mathrm{PL}-\mathrm{PFC}$; acute & $\downarrow$ freezing behavior/CFC & [118] \\
\hline & $0.4 \mu \mathrm{g}$; IL-PFC; 3 days & Improve extinction/CFC & [119] \\
\hline & 10-30 pmol; dorsal HIP; acute & $\downarrow$ Memory consolidation/CFC & [120] \\
\hline & $10 \mathrm{mg} / \mathrm{kg}$; bilateral intra-PFC & $\downarrow$ Memory consolidation/CFC & [109] \\
\hline & 10-60 nmol/side; intra-IL or intra-PL; acute & Antidepressant/FST & [121] \\
\hline Sprague-Dawley rats & $\begin{array}{l}10 \mathrm{mg} / \mathrm{kg} \text {; i.p.; } 7 \text { days } \\
30 \mathrm{mg} / \mathrm{kg} \text {; i.p.; } 7 \text { days }\end{array}$ & Antidepressant/FST & [122] \\
\hline Lister-hooded rats & 10 mg/kg; i.p.; 14 days & $\uparrow$ Freezing behavior/CFC & [123] \\
\hline Flinders Sensitive rats & $\begin{array}{l}\text { 7-30 mg/kg; i.p.; acute } \\
30 \mathrm{mg} / \mathrm{kg} \text {; p.o.; acute }\end{array}$ & Antidepressant/FST & $\begin{array}{l}{[107]} \\
{[110]}\end{array}$ \\
\hline Flinders Resistant rats & 7-30 mg/kg; i.p.; acute & Antidepressant/FST & [107] \\
\hline \multirow{2}{*}{ Wistar Kyoto rats } & 30 mg/kg; p.o.; acute & Antidepressant/FST & [110] \\
\hline & $30 \mathrm{mg} / \mathrm{kg}$; i.p.; acute & Antidepressant/SP and OR & [124] \\
\hline $\begin{array}{l}\text { Spontaneously } \\
\text { Hypertensive rats }\end{array}$ & $1-60 \mathrm{mg} / \mathrm{kg}$; i.p. & No effect/SI & [99] \\
\hline DBT rats & $30 \mathrm{mg} / \mathrm{kg}$; i.p.; sub-chronic & Antidepressant/FST & [125] \\
\hline NGL rats & $0.3 \mathrm{mg} / \mathrm{kg}$; i.p.; acute & Antidepressant/FST & [125] \\
\hline \multirow{6}{*}{ C57Bl/6J mice } & $\begin{array}{c}1 \mathrm{mg} / \mathrm{kg} \text {; i.p.; acute } \\
1 \mathrm{mg} / \mathrm{kg} \text {; i.p.; } 21 \text { days }\end{array}$ & $\begin{array}{l}\text { No effect/OF and EPM } \\
\text { Anxiolytic/LDB }\end{array}$ & [126] \\
\hline & 1,10 and $10 \mathrm{mg} / \mathrm{kg}$; i.p.; acute & No effect/CFC & [127] \\
\hline & $30 \mathrm{mg} / \mathrm{kg}$; i.p.; acute & $\downarrow$ freezing behavior/CFC & [127] \\
\hline & 5,10 or $20 \mathrm{mg} / \mathrm{kg}$; i.p.; acute & No effect/EPM & [128] \\
\hline & 10 mg/kg; i.p.; acute & $\begin{array}{c}\text { No effect/OF } \\
\text { No effect/THC-induced anxiety }\end{array}$ & {$[105,106]$} \\
\hline & 15 mg/kg; i.p. (+ FLX, 3 mg/kg; i.p.); acute & Anxiolytic/MBT & [103] \\
\hline
\end{tabular}


Table 2. Cont.

\begin{tabular}{|c|c|c|c|}
\hline Strain & Doses and Route of Administration & Effect and Test & Reference \\
\hline \multirow{9}{*}{ C57Bl/6J mice } & 20 mg/kg/day; i.p.; 3 weeks & Anxiolytic/PTSD model & [129] \\
\hline & $20 \mathrm{mg} / \mathrm{kg}$; i.p.; 6 weeks & No effect/LBD and OF & [130] \\
\hline & $20 \mathrm{mg} / \mathrm{kg}$; i.p.; 3 weeks & Anxiogenic/EPM & [128] \\
\hline & 15,30 and $60 \mathrm{mg} / \mathrm{kg}$; i.p.; acute & $\begin{array}{c}\text { Anxiolytic/MBT * } \\
* \text { (even } 7 \text { days after its administration })\end{array}$ & [104] \\
\hline & $30 \mathrm{mg} / \mathrm{kg}$; i.p.; chronic & Anxiolytic and antidepressant/CMS & [131] \\
\hline & $30 \mathrm{mg} / \mathrm{kg}$; i.p.; 14 days & Antidepressant/CMS & [116] \\
\hline & 50 mg/kg; i.p.; 21 days & Anxiolytic/OF & [126] \\
\hline & 50 mg/kg; i.p.; acute & No effect/OF and EPM & [126] \\
\hline & $\begin{array}{c}50 \mathrm{mg} / \mathrm{kg} \text {; i.p.; acute } \\
50 \mathrm{mg} / \mathrm{kg} \text {; i.p.; } 3 \text { days and } 10 \mathrm{mg} / \mathrm{kg} ; 11 \text { days }\end{array}$ & $\begin{array}{c}\text { Anxiolytic/OF } \\
\text { Antidepressant/SP }\end{array}$ & [132] \\
\hline \multirow{11}{*}{$\begin{array}{l}\text { ICR mice } \\
\text { Swiss Albino }\end{array}$} & $0.5,1,2.5,5,10$ and $50 \mathrm{mg} / \mathrm{kg}$; i.p.; acute & Anxiolytic/EPM & [98] \\
\hline & 0.01, 0.1 and $100 \mathrm{mg} / \mathrm{kg}$; i.p.; acute & No effect/EPM & [98] \\
\hline & $3 \mathrm{mg} / \mathrm{kg}$; i.p.; acute & Anxiolytic/EPM & [133] \\
\hline & 10 or $30 \mathrm{mg} / \mathrm{kg}$; i.p.; acute & No effect/EPM & [133] \\
\hline & 3,10 or $30 \mathrm{mg} / \mathrm{kg}$; i.p.; chronic & No effect/EPM & [133] \\
\hline & 7-30 mg/kg; i.p.; acute & Antidepressant/FST & [107] \\
\hline & $\begin{array}{c}10 \mathrm{mg} / \mathrm{kg} \text {; i.v.; } 21 \text { days } \\
100 \mathrm{mg} / \mathrm{kg} \text {; p.o.; } 21 \text { days }\end{array}$ & Antidepressant/CMS & {$[134]$} \\
\hline & $\begin{array}{l}0.7 \mathrm{mg} / \mathrm{kg} \text {; i.p.; (plus } 0.1 \mathrm{mg} / \mathrm{kg} \text {; i.p. } \\
\text { 5-AZAD or RG108) }\end{array}$ & Antidepressant/FST & [135] \\
\hline & $\begin{array}{c}7 \mathrm{mg} / \mathrm{kg} ; \text { i.p. (plus FLX } 5 \mathrm{mg} / \mathrm{kg} ; \text { i.p. or DES } \\
2.5 \mathrm{mg} / \mathrm{kg} ; \text { i.p.) }\end{array}$ & Antidepressant/FST & [136] \\
\hline & 10 mg/kg; i.p.; acute & Antidepressant/FST & [135] \\
\hline & $30 \mathrm{mg} / \mathrm{kg}$; i.p.; acute & Antidepressant/FST & [137] \\
\hline \multirow{2}{*}{ Swiss Webster mice } & 2 and $100 \mathrm{mg} / \mathrm{kg}$; i.p.; acute & No effect/FST & [138] \\
\hline & 200 mg/kg; i.p.; acute & Antidepressant/FST & [138] \\
\hline $\mathrm{DBA} / 2$ mice & 2, 100 and $200 \mathrm{mg} / \mathrm{kg}$; i.p.; acute & No effect/TST & [138] \\
\hline
\end{tabular}

BNST: bed nucleus of the stria terminalis; CFC: contextual fear conditioning; CMS: chronic mild stress; DBT: diabetic rats; EPM: elevated plus maze; ES dPAG: electrical stimulation dorsal periaqueductal gray; ETM: elevated T-maze; FLX: fluoxetine; FST: forced swim test; GSP: Geller-Seifter paradigm; HIP: hippocampus; icv: intracerebroventricular; IL: infralimbic; IL-PFC: infralimbic prefrontal cortex; i.p.: intraperitoneal; LDB: light dark-box; MBT: marble-burying test; mPFC: medial prefrontal cortex; NGL: normoglycemic rats; OF: open field; OR: object recognition; PAG: periaqueductal gray; PFC: prefrontal cortex; PL: prelimbic; PL-PFC: prelimbic prefrontal cortex; p.o.: oral administration; PTSD: post-traumatic stress disorder; SI: social interaction; SP: sucrose preference; TST: tail suspension test; VCT: Vogel conflict test; $\downarrow$ : decrease; $\uparrow:$ increase.

Complementary results indicated that the strain and pattern of administration (single and repeated) may affect CBD actions. In male C57BL/6 mice and spontaneously hypertensive rats, CBD failed to induce any effect $[99,105]$. Regarding the pattern of administration, chronic treatment with CBD induced an anxiolytic-like effect, whereas acute administration did not [126]. However, another study reported the opposite results [133].

Other authors have evaluated the influence of age and gender in CBD anxiolytic effects. Chronic CBD administration produced an anxiolytic-like effect when given to mice at 5 months, but not at 3 months of age [130]. However, this group of mice significantly reduced its locomotor activity. This may act as a confounding variable when interpreting the results. In contrast, in another study no effects were found in either adolescent or in adult male mice. Moreover, CBD increased anxiety in adult female mice, suggesting sex-dependent effects [128].

Administering CBD also produced interesting findings in specific brain regions. Microinjections into the bed nucleus of stria terminalis [114] and periaqueductal gray [112,113] showed anxiolytic and panicolytic-like effects, respectively. On the other hand, intracisternal or intra-prelimbic medial prefrontal cortex injection of CBD blocked the autonomic activation and anxiogenic-like responses induced by restraint stress $[115,139]$. These effects appear to be related with $5-\mathrm{HT}_{1 \mathrm{~A}}$ receptors $[112,113,139]$. 
In the fear-conditioning model, a type of associative learning task, acute administration of CBD reduced contextual fear- and anxiety-related behaviors [127,140], whereas chronic administration induced just the opposite [123]. Similarly, microinjections/infusions on specific brain regions, such as intracerebroventricular [117] and prelimbic medial prefrontal cortex, reduced freezing and anxiety [118]. However, infralimbic prefrontal cortex infusion showed contradictory results, increasing freezing [118] or facilitating fear extinction [119], depending on the total number of microinjections given. Indeed, CBD seems to disrupt aversive memory consolidation [109,120], involving anandamide, $\mathrm{CB}_{1} \mathrm{r}, \mathrm{CB}_{2} \mathrm{r}$, and peroxisome proliferator-activated receptor gamma (PPAR $\gamma$ ) receptors in a time-dependent manner $[70,119,120]$. CBD also reduced the influence of PFC on corticolimbic circuits, modulating dopamine and immediate gene expression (c-fos and zif-268 proteins) $[118,141]$, and it functionally modified the mesolimbic circuit through the direct activation of $5-\mathrm{HT}_{1 \mathrm{~A}}$ receptors $[142,143]$.

The efficacy of CBD for reducing fear conditioning, together with its anxiolytic properties, stimulated the development of studies focused on evaluating its potential efficacy in animal models of PTSD, a psychiatric disorder currently classified as trauma and a stressor-related disorder. Acute or sub-chronic administration of CBD reduced the long-lasting anxiogenic-like effects induced by predator stress exposure, suggesting the intervention of $5-\mathrm{HT}_{1 \mathrm{~A}}$ receptors in these actions [144-146]. Furthermore, a new mice model of PTSD conducted by our research team showed that the administration of CBD alone or in combination with sertraline significantly reduced fear conditioning, anxiety-like behaviors and long-term gene expression alterations in the HPA axis, ECS and serotonin systems. These results support the efficacy of CBD, reducing the intense and long-lasting effects of the PTSD model [129].

Along with its anxiolytic properties, CBD displayed antidepressant efficacy in animal models of depression, inducing an antidepressant-like effect when given alone [137] or in combination with sub-effective doses of the antidepressants fluoxetine or desipramine [136], mainly through the activation of $5 \mathrm{HT}_{1 \mathrm{~A}}$ serotonergic receptors [137]. More importantly, $\mathrm{CBD}$ showed a rapid and sustained antidepressant effect. A single dose of CBD induced a dose-dependent antidepressant-like effect in Swiss mice, even 7 days after its administration. Similar results were found in Flinders Sensitive and Flinders Resistant Line (FSL/FRL) rats and in Wistar rats [107]. Neuroplasticity changes were also associated, since synaptophysin, postsynaptic density protein 95 (PSD95) and brain-delivered neurotrophic factor were increased on the pre-frontal cortex (PFC) and hippocampus (HIPP) after CBD administration. This effect involves the activation of tropomyosin receptor kinase $\mathrm{B} /$ mammalian target of rapamycin (TrkB/mTOR) signaling [107]. Moreover, treatment with DNA methylation inhibitors (5-AzaD and RG108) and CBD induced an antidepressant-like effect, preventing the alterations induced by stress exposure on DNA methylation and DNA methyltransferase (DNMT) activity in the HIPP and PFC [135]. This study supports the involvement of epigenetic mechanisms on CBD antidepressant properties.

Additional results indicated that the doses and the strain of rodent used may modulate the effects of CBD. In Swiss Webster mice, only the highest dose induced an antidepressant-like effect, whereas no effect was observed in DBA/2 mice [138]. Furthermore, a recent study suggested that the actions of CBD may be gender-specific, since antidepressant-like effects were found in male but not in female FSL rats [110].

Potential differences due to the pattern of CBD administration (acute vs. chronic) were also explored. In C57BL/6J mice submitted to an olfactory bulbectomy, a rodent model of depression, single and chronic administration of CBD induced anxiolytic and antidepressant-like effects. These behavioral alterations were accompanied by increases of serotonin and glutamate levels in the PFC and $5-\mathrm{HT}_{1 \mathrm{~A}}$ receptor function on the dorsal raphe, CA1-CA2 fields of the HIPP, amygdala and medial PFC [132]. The study further supported the involvement of the 5- $\mathrm{HT}_{1 \mathrm{~A}}$ receptor rather than $\mathrm{CB}_{1} \mathrm{r}$ on $\mathrm{CBD}$ effects. Similar antidepressant-like effects were observed in Wistar rats [111] and Wistar-Kyoto rats as well as in a genetic model of depression [124] and in animal models displaying depressive-like symptoms such as the diabetic and normoglycemic rats [125]. Moreover, specific brain site microinjections of CBD, 
e.g., intra-IL or intra-prelimbic, induced antidepressant-like effects in Wistar rats involving $5-\mathrm{HT}_{1 \mathrm{~A}}$ and $\mathrm{CB}_{1}$ receptors [121].

The administration of CBD displayed antidepressant-like effects at different doses in adolescents and adult male Sprague-Dawley rats [122]. The long-lasting effects of CBD were different: 2 days for adolescent and 21 days for adult rats. Therefore, the outcome appears to depend on the age at which the CBD treatment was administered. Taken together, these findings are relevant to further explore efficacy and safety depending on the patient's age and gender.

The effects of CBD were also evaluated for chronic unpredictable mild stress, an animal model that involved the presentation of repeated mild stressors for several weeks. Following this exposure, rodents exhibited depressive-like behavioral alterations, mainly a persistent reduction of their responsiveness to pleasurable stimuli, such as a palatable sucrose solution $[147,148]$. In this model, different doses and routes of CBD administration prevented anxiogenic and depressogenic-like behaviors and displayed a neuroprotective effect $[116,134,149]$ through $\mathrm{CB}_{1} \mathrm{r}$ and $\mathrm{CB}_{2} \mathrm{r}[116,131]$. Indeed, culture cell studies showed that CBD induced progenitor proliferation and cell cycle progression, depending on $\mathrm{CB}_{1} \mathrm{r}$ and $\mathrm{CB}_{2} \mathrm{r}$ activation and anandamide increase [149]. Overall, these results support the involvement of the endocannabinoid system in the antidepressant-like effects of CBD.

\subsection{Results from Clinical Studies}

\subsubsection{Clinical Studies Focused on Anxiety Disorders}

The first clinical trials evaluating the anxiolytic properties of CBD were conducted in 1974 and 1982, suggesting that CBD alleviates THC-induced anxiety in healthy male volunteers $[150,151]$ (Table 3 ). Subsequently, additional double-blind studies further evaluated the effects of CBD on healthy volunteers. Oral CBD administration decreased anxiety in healthy subjects exposed to the simulated public speaking test [152]. Accordingly, in another double-blind study, CBD significantly reduced subjective anxiety, evaluated by the Visual Analogue Mood Scale (VAMS), and increased mental sedation. These effects were associated with less activity on the medial temporal cluster (left amygdala-hippocampal complex, extending into the hypothalamus), and the left posterior cingulate gyrus, and with high activity on the left parahippocampal gyrus [153]. 
Table 3. Main outcomes achieved from clinical trials of CBD for anxiety, PTSD and depressive disorders.

\begin{tabular}{|c|c|c|c|c|c|}
\hline Clinical Condition & Clinical Trial Design & Sample Size and Gender & $\begin{array}{c}\text { Doses and Route of CBD } \\
\text { Administration }\end{array}$ & Outcomes & References \\
\hline Healthy volunteers & $\begin{array}{l}\text { Double-blind randomized } \\
\text { placebo-controlled trial }\end{array}$ & $\begin{array}{c}40 \mathrm{M} \\
(\mathrm{N}=5 / \text { group })\end{array}$ & $\begin{array}{l}15-60 \mathrm{mg} \text { dissolved in } \\
\text { ethanol and orange juice; } \\
\text { p.o.; acute }\end{array}$ & $\downarrow$ THC-induced anxiety & [150] \\
\hline Healthy volunteers & $\begin{array}{l}\text { Double-blind randomized } \\
\text { placebo- and } \\
\text { diazepam-controlled trial }\end{array}$ & $\begin{array}{c}8 \\
(6 \mathrm{M} / 2 \mathrm{~F})\end{array}$ & $\begin{array}{l}0.5 \mathrm{mg} / \mathrm{kg} \text {; dissolved in } \\
\text { ethanol and artificial lemon } \\
\text { juice; p.o.; acute }\end{array}$ & $\downarrow$ THC-induced anxiety & [151] \\
\hline Healthy volunteers & $\begin{array}{l}\text { Double-blind randomized } \\
\text { placebo-controlled trial }\end{array}$ & $\begin{array}{c}40 \\
(18 \mathrm{M} / 22 \mathrm{~F})\end{array}$ & $\begin{array}{l}300 \text { mg dissolved in corn oil } \\
\text { and given in gelatin } \\
\text { capsules; p.o.; acute }\end{array}$ & $\begin{array}{l}\text { Stimulated public } \\
\text { speaking test }\end{array}$ & [152] \\
\hline Healthy volunteers & $\begin{array}{l}\text { Double-blind randomized } \\
\text { placebo-controlled trial }\end{array}$ & $\begin{array}{c}10 \mathrm{M} \\
(\mathrm{N}=5 / \text { group })\end{array}$ & $\begin{array}{l}400 \text { mg dissolved in corn oil } \\
\text { and given in gelatin } \\
\text { capsules; p.o.; acute }\end{array}$ & $\begin{array}{l}\downarrow \text { Subjective anxiety } \\
\uparrow \text { Mental sedation }\end{array}$ & [153] \\
\hline $\begin{array}{l}\text { Healthy volunteers } \\
\text { (Cannabis sativa users) }\end{array}$ & $\begin{array}{l}\text { Double-blind, randomized, } \\
\text { placebo-controlled trial, } \\
\text { repeated-measures } \\
\text { within-subject vs. placebo }\end{array}$ & $15 \mathrm{M}$ & $\begin{array}{l}600 \text { mg; gelatin capsules; } \\
\text { p.o.; } 3 \text { separate sessions }\end{array}$ & $\begin{array}{c}\text { No behavioral or regional } \\
\text { brain activation }\end{array}$ & [154] \\
\hline Healthy volunteers & $\begin{array}{l}\text { Double-blind, } \\
\text { repeated-measures vs. placebo }\end{array}$ & $16 \mathrm{M}$ & $\begin{array}{l}600 \text { mg; opaque capsules; } \\
\text { p.o.; } 3 \text { consecutive sessions }\end{array}$ & $\begin{array}{l}\text { No psychotic symptoms, } \\
\text { mental sedation, } \\
\text { intellectual impairment or } \\
\text { physical sedation }\end{array}$ & {$[35]$} \\
\hline $\begin{array}{l}\text { Treatment-naïve } \\
\text { SAD patients }\end{array}$ & $\begin{array}{l}\text { Double-blind randomized } \\
\text { placebo-controlled trial }\end{array}$ & $10 \mathrm{M}$ & $\begin{array}{l}400 \text { mg dissolved in corn oil } \\
\text { and packed inside gelatin } \\
\text { capsules; p.o.; acute }\end{array}$ & $\begin{array}{l}\downarrow \text { Subjective anxiety } \\
\text { Changes in regional } \\
\text { cerebral flow }\end{array}$ & [155] \\
\hline $\begin{array}{l}\text { Treatment-naïve } \\
\text { SAD patients }\end{array}$ & $\begin{array}{l}\text { Double-blind randomized } \\
\text { placebo-controlled trial }\end{array}$ & $12 \mathrm{M}$ & $\begin{array}{l}600 \text { mg dissolved in corn oil } \\
\text { and packed inside gelatin } \\
\text { capsules; p.o.; acute }\end{array}$ & $\begin{array}{c}\downarrow \text { Subjective anxiety } \\
\downarrow \text { Cognitive impairment }\end{array}$ & [156] \\
\hline
\end{tabular}


Table 3. Cont.

\begin{tabular}{|c|c|c|c|c|c|}
\hline Clinical Condition & Clinical Trial Design & Sample Size and Gender & $\begin{array}{c}\text { Doses and Route of CBD } \\
\text { Administration }\end{array}$ & Outcomes & References \\
\hline $\begin{array}{l}\text { Psychiatric patients } \\
\text { with primary concern of } \\
\text { anxiety or poor sleep }\end{array}$ & $\begin{array}{l}\text { Large retrospective case series } \\
\text { (adjunct to usual treatment) }\end{array}$ & $\begin{array}{c}47 \text { anxiety }(28 \mathrm{M} / 19 \mathrm{~F}) \\
25 \text { poor sleep }(16 \mathrm{M} / 9 \mathrm{~F})\end{array}$ & $\begin{array}{l}25 \mathrm{mg} / \text { day to } 50-75 \mathrm{mg} / \text { day; } \\
\text { capsule; } 1-3 \text { months }\end{array}$ & $\begin{array}{c}\downarrow \text { Anxiety } \\
\text { Improved sleep } \\
\text { disturbances }\end{array}$ & [157] \\
\hline $\begin{array}{l}\text { Non-clinical volunteers } \\
\text { with high } \\
\text { paranoid traits }\end{array}$ & $\begin{array}{l}\text { Double-blind randomized } \\
\text { placebo-controlled trial }\end{array}$ & $\begin{array}{l}32(16 \mathrm{M} / 16 \mathrm{~F}) \\
\mathrm{N}=8 / \text { group }\end{array}$ & $\begin{array}{l}600 \mathrm{mg} \text {; hard gelatin } \\
\text { capsule; p.o.; acute }\end{array}$ & $\begin{array}{c}\uparrow \text { Anxiety } \\
\text { No effects persecutory } \\
\text { ideation }\end{array}$ & [158] \\
\hline Cannabis use disorder & $\begin{array}{l}\text { Double-blind randomized } \\
\text { placebo-controlled trial }\end{array}$ & $\begin{array}{c}51 \\
\text { CBD N }=27(18 \mathrm{M} / 9 \mathrm{~F}) \\
\text { Placebo } \mathrm{N}=24(21 \mathrm{M} / 3 \mathrm{~F})\end{array}$ & $\begin{array}{l}\text { Nabiximols (CBD } 2.5 \mathrm{mg} \\
\text { plus THC } 2.7 \mathrm{mg}) ; 6 \text { days }\end{array}$ & $\begin{array}{c}\downarrow \text { Anxiety } \\
\downarrow \text { Craving } \\
\downarrow \text { Depression }\end{array}$ & [159] \\
\hline $\begin{array}{l}\text { Volunteers selected for } \\
\text { high and low frequency } \\
\text { of cannabis use and } \\
\text { schizotypy (males } \\
\text { and females }\end{array}$ & $\begin{array}{l}\text { Double-blind, randomized } \\
\text { placebo-controlled trial }\end{array}$ & $\begin{array}{c}48 \\
\text { LSS group } \mathrm{N}=12(9 \mathrm{M}: 3 \mathrm{~F}) \\
\text { LHS group } \mathrm{N}=12(7 \mathrm{M}: 5 \mathrm{~F}) \\
\text { HLS group } \mathrm{N}=12(11 \mathrm{M} / 1 \mathrm{~F}) \\
\text { HHS group } \mathrm{N}=12(7 \mathrm{M}: 5 \mathrm{~F})\end{array}$ & $\begin{array}{l}16 \mathrm{mg} \text {, formulated in } \\
\text { alcohol solution; } \\
\text { vaporization }\end{array}$ & $\begin{array}{l}\text { Improved emotional } \\
\text { processing }\end{array}$ & [160] \\
\hline $\begin{array}{l}\text { Drug-abstinent patients } \\
\text { with heroin } \\
\text { user disorder }\end{array}$ & $\begin{array}{l}\text { Double-blind randomized } \\
\text { placebo-controlled trial }\end{array}$ & $\begin{array}{c}42 \\
\text { CBD } 400 \mathrm{mg} \mathrm{N}=14(12 \mathrm{M} / 2 \mathrm{~F}) \\
\text { CBD } 800 \mathrm{mg} \mathrm{N}=13(11 \mathrm{M} / 2 \mathrm{~F}) \\
\text { Placebo } \mathrm{N}=15(12 \mathrm{M} / 3 \mathrm{~F})\end{array}$ & $\begin{array}{l}400(\mathrm{n}=14) \text { or } 800 \mathrm{mg} \\
(\mathrm{n}=13) ; \text { once daily; } \\
\text { oral solution Epidiolex; } \\
\text { acute }(1,2 \text { or } 24 \mathrm{~h}) \text { and } \\
\text { Short-term administration } \\
\quad(3 \text { consecutive day })\end{array}$ & $\begin{array}{c}\downarrow \text { Anxiety } \\
\downarrow \text { Craving } \\
\downarrow \text { Heart rate } \\
\downarrow \text { Salivary cortisol levels }\end{array}$ & [161] \\
\hline Healthy volunteers & $\begin{array}{l}\text { Double-blind, } \\
\text { pseudo-randomized, } \\
\text { placebo-controlled, } \\
\text { repeated-measures, } \\
\text { within-subject design }\end{array}$ & $15 \mathrm{M}$ & $\begin{array}{l}600 \text { mg; capsules; p.o.; } \\
3 \text { consecutive sessions }\end{array}$ & $\begin{array}{c}\text { Altered } \\
\text { prefrontal-subcortical } \\
\text { connectivity/response to } \\
\text { fearful faces }\end{array}$ & [162] \\
\hline
\end{tabular}


Table 3. Cont.

\begin{tabular}{|c|c|c|c|c|c|}
\hline Clinical Condition & Clinical Trial Design & Sample Size and Gender & $\begin{array}{c}\text { Doses and Route of CBD } \\
\text { Administration }\end{array}$ & Outcomes & References \\
\hline PTSD & Open-label & $\begin{array}{c}11 \\
(8 \mathrm{~F} / 3 \mathrm{M})\end{array}$ & $\begin{array}{l}\text { Flexible doses: starting at } 25 \\
\text { to } 48.64 \mathrm{mg} / \text { day; capsule or } \\
\text { liquid spray; } 8 \text { weeks }\end{array}$ & $\downarrow$ PTSD severity & [163] \\
\hline Regular cannabis users & Open-label & $\begin{array}{c}18 \\
(14 \mathrm{M} / 4 \mathrm{~F})\end{array}$ & $\begin{array}{c}200 \mathrm{mg} / \text { day }(99.5 \% \text { pure } \\
\text { crystalline of herbal origin); } \\
\text { gelatin-coated capsules; } \\
10 \text { weeks }\end{array}$ & $\begin{array}{c}\downarrow \text { Depressive } \\
\downarrow \text { Psychotic symptoms }\end{array}$ & [164] \\
\hline Regular cannabis users & Open-label & $\begin{array}{c}20 \\
(16 \mathrm{M} / 4 \mathrm{~F})\end{array}$ & $\begin{array}{c}200 \mathrm{mg} / \text { day ( } 99.5 \% \text { pure } \\
\text { crystalline of herbal origin); } \\
\text { gelatin-coated capsules; } \\
10 \text { weeks }\end{array}$ & $\begin{array}{c}\downarrow \text { Depressive symptoms } \\
\downarrow \text { Psychotic symptoms } \\
\uparrow \text { Attentional switching } \\
\uparrow \text { Verbal learning } \\
\uparrow \text { Memory }\end{array}$ & [165] \\
\hline
\end{tabular}

CBD: cannabidiol; F: Female; HHS: heavy high schizotypy; HLS: heavy low schizotypy; LHS: light high schizotypy; LLS: light low schizotypy; M: Male; PTSD: post-traumatic stress disorder; SAD: social anxiety disorder; THC: tetrahydrocannabinol; $\downarrow$ reduction of; $\uparrow$ increase of. 
In a double-blind randomized placebo-controlled trial using a repeated-measures within-subject design in healthy volunteers who had used Cannabis sativa 15 times or less, CBD did not induce any behavioral or regional brain activation in the verbal learning task compared to placebo, in contrast to THC [154]. Similarly, a crossover, double-blind, repeated-measures design in 16 healthy male volunteers revealed that, unlike $\Delta^{9}$-THC, CBD did not induce psychotic symptoms, mental sedation, intellectual impairment, or physical sedation compared to placebo [35].

The anxiolytic efficacy of CBD was evaluated in patients diagnosed with anxiety disorders. In treatment-naïve patients with $\mathrm{SAD}, \mathrm{CBD}$ reduced subjective anxiety, inducing changes in regional cerebral flow $[155,156]$. A large retrospective case series including psychiatric patients whose primary concern was anxiety or poor sleep suggested that the administration of CBD decreased anxiety rapidly and in a sustained manner. CBD also improved sleep disturbances within the first month of treatment but with fluctuations over the total three-month period evaluated [157]. However, in a clinical trial performed in non-clinical volunteers with high paranoid traits, CBD increased anxiety and had no effects on persecutory ideation in a controlled three-dimensional (3D) virtual-reality scenario [158]. These results suggest, in contrast to those observed in SAD patients, that CBD failed to display an anxiolytic-like effect in healthy volunteers with high paranoid traits.

Additional results supporting the anxiolytic properties of CBD come from clinical trials suggesting that nabiximols, a medication containing THC (2.7 mg) and CBD (2.5 mg) and used to treat spasticity in multiple sclerosis, reduced anxiety, and craving in patients with cannabis use disorder [159]. A previous case report indicated that oral CBD administration reduced cannabis withdrawal, anxiety and dissociative symptoms [166]. Besides, acute CBD vaporization improved emotional processing affect recognition and prevented the impairment of ambiguous face recognition induced by THC [160]. Similarly, in a double-blind, randomized, placebo-controlled trial in heroin users, CBD reduced anxiety and craving after its acute administration, with effects that remained stable even after 7 days [161].

Neuroimaging studies revealed that the administration of CBD altered prefrontal-subcortical connectivity during the response to fearful faces. The connection between anterior cingulate cortex-amygdala was disrupted after the administration of CBD. This finding was associated with a concurrent electrophysiological effect, pointing out both brain regions as potential key targets underlying the anxiolytic actions of CBD [162].

Additional ongoing trials have been identified. An open-label clinical trial (NCT02548559) is evaluating the effects of CBD to reduce anxiety in adults (16 participants) [167]. CBD will be given as a sublingual tincture delivered from the whole plant in a total daily dose of $30 \mathrm{mg}$ for 4 weeks. Changes in anxiety behavior will be measured every week by using different scales. Following this phase 1 trial, a double-blind phase 2 clinical trial (NCT04286594) will begin following the same procedure in 75 patients diagnosed with anxiety [168].

In addition, a placebo-controlled phase 3 trial (NCT03549819) in adults is assessing the efficacy of CBD (oil capsules; flexibly dosed at 200-800 mg per day for 4 weeks) to reduce symptoms in patients diagnosed with generalized anxiety disorder, SAD, panic disorder, or agoraphobia [169]. Similarly, the goal of the pilot trial (NCT04267679) is to show the efficacy of CBD (soft gel capsules; up to a total of $100 \mathrm{mg} /$ day; 12 weeks) to decrease anxiety and sleep disturbances in patients diagnosed with anxiety [170]. 


\subsubsection{Clinical Studies Focused on Stress-Related Disorders: PTSD}

Today, there is a growing number of clinical trials assessing the efficacy of CBD to modulate the severity of PTSD. In an open-label clinical trial carried out in adults diagnosed with PTSD, CBD plus psychiatric medications and psychotherapy reduced the severity of PTSD symptoms after 8 consecutive weeks of treatment [163]. In addition, a double-blind randomized clinical trial (NCT04197102), designed to evaluate the efficacy of CBD ( $300 \mathrm{mg} /$ day for 8 weeks) to reduce PTSD severity, has been recruiting patients since January 2020. Study completion is expected by May 2024 [171]. Moreover, another clinical trial, expected to finish in August 2021, is assessing the efficacy of CBD (600 mg/day for 6 weeks) for reducing alcohol intake in people with PTSD (NCT03248167) [172]. On the other hand, a placebo-controlled clinical trial (NCT02759185) is evaluating the efficacy of 4 types of smoked CBD-containing marijuana (up to 1.8 g per day for 3 weeks) for reducing symptoms severity, including anxiety and depression, in 76 military veterans with PTSD [173].

\subsubsection{Clinical Studies Focused on Depressive Disorders}

Evidence of CBD's antidepressant actions in humans is still scarce. In a clinical trial carried out in patients with chronic pain, high doses of nabiximols significantly reduced mood state [174]. Interestingly, oral CBD significantly decreased depressive and psychotic symptoms in cannabis users, restoring the harmful effects of cannabis on the subiculum and CA1 sub-regions of the HIPP [164]. Similar results were observed in frequent cannabis users in whom oral CBD reduced depressive- and psychotic-like symptoms and improved attentional switching, verbal learning, and memory [165]. Accordingly, nabiximols, used as an agonist replacement therapy during cannabis withdrawal, significantly reduced depression [159]. More recently, CBD users $(n=2409)$ reported mood-improving effects in several medical conditions in an online survey. The study did not discriminate between pure CBD and marijuana-derived CBD products with different components in the formulations [175].

An ongoing double-blind, randomized, placebo-controlled clinical trial (NCT03310593) is evaluating the effects of CBD (150-300 mg/day for 12 weeks) to reduce anxiety and depression in patients with bipolar disorder (estimated enrollment: 100 participants) [176]. The estimated study completion date is April 2022.

Taken together, these studies provide preliminary evidence supporting the efficacy and safety of $\mathrm{CBD}$ on these pathologies, although larger, clinical trials are needed to reach definitive conclusions.

\section{Role of CBD on Schizophrenia}

\subsection{Current Scenario}

SCZ is a heterogeneous psychiatric disorder with onset in late adolescence or early adulthood [177]. While heterogeneous, the symptoms are classified into three main categories: positive symptoms (hallucinations, delusions, disorganized thoughts, and senseless speech, bizarre behaviors); negative symptoms (social withdrawal, anhedonia, lack of emotional and facial expression, reduced speech, reduced ability to begin and sustain activities); and cognitive dysfunctions (impaired executive function, working memory and attention) $[177,178]$. SCZ affects only $1 \%$ of the worldwide population; however, it is a subject of intense research due to the limited efficacy of antipsychotic drugs [179]. Current treatments improve only positive symptoms following the first episode of psychosis in just $50 \%$ to $70 \%$ of patients; they present moderate efficacy for negative symptoms and have no effect on cognitive deficits [180]. At the same time, antipsychotic drugs induce severe side effects, including extrapyramidal symptoms, hyperprolactinemia, and cardiovascular complications or interval QT prolongation (depending on the type of the antipsychotic drug), limiting their chronic use [180]. New antipsychotic drugs have a better risk-benefit balance, but they still show limitations for safety and efficacy. Thus, there is a need to identify new, more effective, safer drugs for the pharmacological management of SCZ [181]. In this respect, CBD has been proposed as a new potential 
treatment based on findings from several preclinical studies, and more recently in clinical trials, showing its antipsychotic effects [182].

\subsection{Results from Animal Studies}

The development of animal models for complex psychiatric disorders, such as SCZ, has been instrumental in increasing our understanding of the neurobiological basis of this disorder and for identifying novel antipsychotic drugs [183]. Different experimental approaches have been used to reproduce the main features of SCZ, mostly in rodents (Table 4). Depending on the type of the manipulation used to induce these alterations, rodent models are classified into developmental models (e.g., maternal immune system's reactivation); pharmacological models (e.g., amphetamine or ketamine administration); and lesion (e.g., neonatal ventral hippocampal lesion) or genetic (e.g., deficient functioning of the DISC1 gene) manipulation models [183]. Jointly, they enable the reproduction of some behaviors simulating positive and negative symptoms, and to a lesser extent, cognitive impairments. 
Table 4. CBD studies on animal models of schizophrenia.

\begin{tabular}{|c|c|c|c|}
\hline Strain & Doses and Route of Administration & Effect and Test & References \\
\hline Wistar rats & 5,12 and $30 \mathrm{mg} / \mathrm{kg}$; i.p.; acute & No effects on behavioral alterations induced by MK-801 & [184] \\
\hline \multirow{7}{*}{ Sprague Dawley rats } & $100 \mathrm{ng} / 0.5 \mu \mathrm{L}$, intra-NAcc; acute & Improve PPI and hyperlocomotion induced by AMPH & [185] \\
\hline & 3,10 and $30 \mathrm{mg} / \mathrm{kg}$, i.p.; acute & No effects on behavioral alterations induced by MK-801 & [186] \\
\hline & 1 and $3 \mathrm{mg} / \mathrm{kg}$; i.p.; acute & $\downarrow$ anxiety and hyperlocomotion induced by MK-801 & [187] \\
\hline & \multirow{3}{*}{$10 \mathrm{mg} / \mathrm{kg}$; i.p.; 11 days } & Anxiolytic and $\uparrow$ recognition and working memory induced by poly I:C given on GD15 & [188] \\
\hline & & Normalization of $\mathrm{CB}_{1} \mathrm{r}$ and glutamate decarboxylase alterations in the PFC and HIPP induced by poly I:C given on GD15 & [189] \\
\hline & & Modulation of muscarinic M1/M4 receptors and choline acetyltransferase levels in PFC and HIPP/poly I:C on GD15 & [190] \\
\hline & 10 and $30 \mathrm{mg} / \mathrm{kg}$; i.p.; 20 days & $\begin{array}{l}\text { Normalization of social withdrawal and cognitive impairment induced by MAM on GD17 } \\
\text { Normalization of } \mathrm{CB}_{1} \mathrm{r} \text { alterations in PFC induced by MAM given on GD17 }\end{array}$ & [191] \\
\hline \multirow{5}{*}{ C57BL/6J mice } & $1,5,10$ and $50 \mathrm{mg} / \mathrm{kg}$; i.p.; chronic & CBD $(50 \mathrm{mg} / \mathrm{kg})$ attenuated hyperlocomotion induced by DEXAMPH & [126] \\
\hline & 15,30 and $60 \mathrm{mg} / \mathrm{kg}$; i.p.; 21 days & Dose-dependent attenuation of MK-801-induced disruption in PPI & [192] \\
\hline & 30 and $60 \mathrm{mg} / \mathrm{kg}$; i.p.; 21 days & Improvement of anxiety and cognitive impairment induced by MK-801 & [193] \\
\hline & 15,30 and $60 \mathrm{mg} / \mathrm{kg}$; i.p.; 1 week & Improvement of anxiety and cognitive impairment induced by MK-801 & [194] \\
\hline & $1 \mathrm{mg} / \mathrm{kg}$; i.p.; 30 days & Attenuation of motor hyperactivity on PND90 induced by poly I:C given on GD9 & [195] \\
\hline \multirow{3}{*}{ Swiss mice } & 15,30 and $60 \mathrm{mg} / \mathrm{kg}$; i.p.; acute & $\begin{array}{l}\text { CBD (30 and } 60 \mathrm{mg} / \mathrm{kg} \text { ) blocked AMPH-induced hyperlocomotion } \\
\text { CBD }(60 \mathrm{mg} / \mathrm{kg} \text { ) attenuated KET-induced hyperlocomotion }\end{array}$ & [196] \\
\hline & $\begin{array}{c}15,30 \& 60 \mathrm{mg} / \mathrm{kg} \text {; i.p. } \\
60 \mathrm{nmol} \text { in } 0.2 \mu \mathrm{L} ; \text { intra-NAcc; acute }\end{array}$ & Attenuation of PPI alterations induced by AMPH & [197] \\
\hline & $15 \mathrm{mg} / \mathrm{kg}$; i.p.; acute & Modulation of PPI disruption induced by MK-801 & [198] \\
\hline Nrg1 HET mice & 1,50 and $100 \mathrm{mg} / \mathrm{kg}$; i.p.; 21 days & $\begin{array}{c}\text { CBD (50 and } 100 \mathrm{mg} / \mathrm{kg} \text { ) improved hyperlocomotion and anxiety } \\
\text { No significant improvement in PPI }\end{array}$ & [199] \\
\hline
\end{tabular}

AMPH: amphetamine; CBD: cannabidiol; DEXAMPH: dexamphetamine; GD: gestational day; HIPP: hippocampus; i.p.: intraperitoneal; KET: ketamine; MAM: methylazoxymethanol acetate;

NAcc: nucleus accumbens; NAM: methylazoxymethanol acetate; Nrg1 HET mice: neuregulin 1 heterozygous mutant mice; PFC: prefrontal cortex; PND: postnatal day; PPI:

prepulse inhibition. $\downarrow$ decrease; $\uparrow$ increase. 
A large number of these animal models have been used to assess the potential efficacy of CBD for modulating SCZ-related behavioral and neurobiological alterations. One of the most frequent symptoms in people with SCZ is psychomotor agitation, which is pharmacologically reproduced in rodents by administering dopamine receptor agonists such as amphetamine or dexamphetamine. Antipsychotic drugs can modulate this drug-induced motor hyperactivity. In this model, a high dose of CBD reduced amphetamine- and dexamphetamine-induced motor hyperactivity, without causing additional motor effects [126,196]. Similarly, CBD normalized ketamine-motor hyperactivity when given chronically, but not acutely. Interestingly, CBD did not induce catalepsy, showing a similar profile as atypical antipsychotics [196].

Another frequent symptom in schizophrenia is the inability to filter out irrelevant stimuli or make associations for further processing, both effects that are linked to alterations in sensorimotor gating. In animal models, these alterations are measured by the pre-pulse inhibition (PPI) of the startle response, which enables the evaluation of SCZ-like behaviors and the efficacy of new potential antipsychotics. In this model, systemic or intra-nucleus accumbens (NAcc) pre-treatment with CBD attenuated the amphetamine-induced PPI alterations in Swiss mice [197]. In the same study, the authors reported similar results after pre-treatment with the anandamide hydrolysis inhibitor URB597, suggesting that the improvement achieved with CBD may be related with its ability to increase anandamide availability $[67,200]$. These results are consistent with those found in a clinical study, further explained in the next section of this review, studying the parallels between the improvement of SCZ-related symptoms following administration of CBD and the increase in plasma concentrations of anandamide [201]. Furthermore, similar PPI and locomotor hyperactivity normalization were found in rats pre-treated with CBD. These behavioral alterations may be associated with the regulation of mTOR/p70S6 kinase pathways phosphorylation in the NAcc shell [185].

CBD has displayed interesting effects in other SCZ animal models. Saletti et al. showed that acute CBD administration fully normalized PPI alterations induced by MK-801, a non-competitive antagonist of NMDA receptors, in capuchin monkeys (Sapajus spp.) [202]. Similarly, both acute [198] and chronic [192] administration of CBD modulated the PPI impairment induced by MK-801 in mice, involving, at least in part, TRPV1 receptors [67,198,203]. Chronic administration of CBD also regulated the impairments induced by MK-801 administration in social interaction and novel object recognition tests in mice, behaviors that try to simulate the negative and cognitive symptoms of SCZ. In this study, the high dose of CBD showed the same efficacy as the antipsychotic drug clozapine [193]. Moreover, social interaction and novelty object recognition tests revealed protective effects of CBD when administered after the end of the MK-801 chronic administration, in which 5- $\mathrm{HT}_{1 \mathrm{~A}}$ receptors appear to play a relevant role [194]. Despite these promising results, in other rodent studies, CBD slightly modulated the PPI impairment induced by MK-801, without normalizing locomotor hyperactivity or social interaction [184,186]. However, pre-treatment with CBD avoided both alterations [187].

More recently, genetic animal models of SCZ, such as the mutant mice of neuregulin1 (Nrg1 HET), have been used to evaluate the potential antipsychotic-like effects of CBD. Neuregulin1 is a protein involved in neuronal migration, myelination and the regulation of glutamatergic NMDA and GABAergic $\mathrm{GABA}_{\mathrm{A}}$ receptors expression (for a review, see [204]). Chronic administration of high doses of CBD increased social interaction in mutant mice, with a modest recovery of PPI impairment [199]. Authors identified an increase of $\mathrm{GABA}_{\mathrm{A}}$ receptor binding in the granular retrosplenial cortex of the mutant mice treated with CBD, suggesting that these GABAergic receptors may be partly responsible for CBD-induced behavioral modulation. In fact, some authors have proposed that CBD may act on GABAergic and glutamatergic systems indirectly, but not exclusively, through its direct action on different targets of the ECS, serotonergic or opioid systems [205]. However, recent in vitro [206] and in vivo [207] studies suggested that CBD modulates the GABAergic system by acting directly on $\mathrm{GABA}_{\mathrm{A}}$ receptors. Consequently, the effects of CBD on the GABAergic circuits may be the result of both direct and indirect modulation of this system. More studies are needed to further investigate the role of the GABAergic system in the antipsychotic-like effects of CBD. 
Epidemiological human studies revealed that exposure to adverse events during pregnancy increases the risk of developing SCZ later on [208]. For this reason, the number of studies attempting to simulate SCZ-like behaviors by exposing pregnant rodents to different disturbances greatly increased in recent years. One of these models is based on the administration of polyinosinic: polycytidylic acid (poly I:C) or the anti-mitotic agent methylazoxymethanol acetate (MAM) on early gestational days (GD) to induce the activation of the maternal immune system. In mice exposed to poly I:C (GD 9 or 15), CBD normalized the increased motor activity [195] and reduced alterations on recognition, working memory, and anxiety [188]. The authors found a normalization of $\mathrm{CB}_{1} \mathrm{r}$ and glutamate decarboxylase in PFC and HIPP, respectively [189]. Similarly, chronic CBD administration at early ages of development modulated long-term behavioral and neurobiological consequences, including $\mathrm{CB}_{1} \mathrm{r}$ brain alterations, induced by MAM administration on GD 17 [191]. Previous studies suggested the involvement of $\mathrm{CB}_{1} \mathrm{r}$ receptors in the antipsychotic-like effects of $\mathrm{CBD}$-one of the first mechanisms described $[26,209]$. However, the interaction between $C B D$ and $\mathrm{CB}_{1} \mathrm{r}$ is controversial. On the one hand, $\mathrm{CBD}$ appears to activate $\mathrm{CB}_{1} \mathrm{r}$ by increasing anandamide levels, probably by inhibiting its reuptake and metabolism [201,210]. Conversely, some reports suggested that CBD may act as a negative allosteric modulator of $\mathrm{CB}_{1} \mathrm{r}[65,66,211,212]$. Consequently, more studies are needed to further explore the role of $\mathrm{CB}_{1} \mathrm{r}$ on the antipsychotic actions of $\mathrm{CBD}$. Similarly, the implication of $\mathrm{CB}_{2} \mathrm{r}$ on $\mathrm{CBD}$ antipsychotic-like actions could be evaluated, since this cannabinoid receptor has been related with SCZ in rodents and humans [213,214], and CBD appears to act as an inverse agonist of such receptors [65,67].

Muscarinic M1/M4 receptors and choline acetyltransferase were also associated with the modulating effects of CBD on poly I:C induced-behavioral alterations [190]. In addition, an in vitro study showed that CBD may also act on dopamine D2 receptors, inhibiting dopamine binding in the homogenized striatal tissue of rats [79]. Notably, the modulation of dopaminergic activity by CBD seems to be brain-region specific, since its administration to patients with psychosis and Parkinson's disease modulated psychotic symptoms without worsening motor activity [215]. Thus, the selective modulation of the dopaminergic system in the striatum enable an antipsychotic effect without extrapyramidal side effects. In addition, both pre-clinical [216] and clinical [201] studies showed that, unlike typical antipsychotics, CBD does not increase plasma prolactin, adding more evidence to support its good safety profile.

Therefore, the existing scientific results suggest that CBD may be useful for modulating SCZ-related features, with a pharmacological profile similar to atypical antipsychotics [182], involving a variety of mechanisms. However, further studies are needed to increase the understanding of CBD efficacy and safety in SCZ.

\subsection{Results from Clinical Studies}

The promising results found in animal models have encouraged the development of clinical trials to evaluate its therapeutic utility for managing people who have or are at high risk of schizophrenia (Table 5). Two clinical trials evaluated the effects of chronic CBD administration $[217,218]$ in stable antipsychotic-treated patients with SCZ. In the first, CBD did not produce changes in positive or negative symptoms, as assessed on the MATRICS Consensus Cognitive Battery (MCCB) and Positive and Negative Syndrome Scale (PANSS) in comparison with placebo. In addition, CBD failed to produce any improvement in cognitive impairments, evaluated with the MATRICS Consensus Cognitive Battery (MCCB) scale. On the other hand, CBD did not induce movement alterations, clearly a great advantage compared with current antipsychotic drugs [217]. Only sedation was significantly prevalent in the CBD-treated group compared to placebo. 
Table 5. Main outcomes achieve from clinical trials in psychosis and schizophrenia.

\begin{tabular}{|c|c|c|c|c|c|c|}
\hline Clinical Condition & Clinical Trial Design & Sample Size and Gender & $\begin{array}{l}\text { Doses and Route of } \\
\text { Administration }\end{array}$ & Outcomes & Adverse Events & References \\
\hline Chronic schizophrenia & $\begin{array}{l}\text { Double-blind, } \\
\text { randomized, } \\
\text { placebo-controlled }\end{array}$ & $\begin{array}{c}36 \\
\text { CBD group N = } 18(12 \mathrm{M} / 6 \mathrm{~F}) \\
\text { Placebo group } \mathrm{N}=18(13 \mathrm{M}: 5 \mathrm{~F})\end{array}$ & $\begin{array}{l}600 \mathrm{mg} / \text { day; p.o.; } \\
6 \text { weeks }\end{array}$ & No improvement in PANSS or MCCB scores & No movement alterations & [217] \\
\hline $\begin{array}{l}\text { Schizophrenia or a } \\
\text { related psychotic disorder }\end{array}$ & $\begin{array}{l}\text { Double-blind } \\
\text { randomized, } \\
\text { placebo-controlled }\end{array}$ & $\begin{array}{c}88 \\
\text { CBD group } \mathrm{N}=42(28 \mathrm{M} / 14 \mathrm{~F}) \\
\text { Placebo group } \mathrm{N}=44(23 \mathrm{M} / 11 \mathrm{~F})\end{array}$ & $\begin{array}{l}1000 \mathrm{mg} / \text { day; oral } \\
\text { solution; p.o.; } 6 \text { weeks }\end{array}$ & $\begin{array}{c}\downarrow \text { Positive symptoms (PANSS) } \\
\text { Improve cognitive performances (BACS) and overall } \\
\text { functioning (GAF) }\end{array}$ & $\begin{array}{l}\text { No prolactin or metabolic alterations; } \\
\text { No weight gain; No liver alterations } \\
\text { Mild GI events }\end{array}$ & [218] \\
\hline $\begin{array}{l}\text { Acute paranoid } \\
\text { schizophrenia }\end{array}$ & $\begin{array}{c}\text { Double-blind, } \\
\text { randomized CBD vs. } \\
\text { amisulpride }\end{array}$ & $\begin{array}{c}39 \\
\text { CBD group } \mathrm{N}=20(15 \mathrm{M} / 5 \mathrm{~F}) \\
\text { Amisulpride group } \mathrm{N}=19(17 \mathrm{M} / 2 \mathrm{~F})\end{array}$ & $\begin{array}{l}800 \mathrm{mg} / \text { day; p.o.; } \\
4 \text { weeks }\end{array}$ & $\downarrow$ PANSS scores (no difference compared to amisulpride) & $\begin{array}{c}\text { Fewer extrapyramidal effects } \\
\text { Less weight gain Lower prolactin increase }\end{array}$ & [201] \\
\hline $\begin{array}{l}\text { Psychosis in the early } \\
\text { stages of illness }\end{array}$ & $\begin{array}{l}\text { Double-blind, } \\
\text { randomized, } \\
\text { placebo-controlled }\end{array}$ & $\begin{array}{l}34 \\
\text { Psychosis group N = } 15 \text { (10 M:5 F) } \\
\text { Healthy controls N = } 19(11 \text { M:5 F) }\end{array}$ & $\begin{array}{l}600 \mathrm{mg} \text {; gelatin } \\
\text { capsules; p.o.; acute }\end{array}$ & $\begin{array}{l}\text { Attenuation of a dysfunctional activation of } \\
\text { mediotemporal and prefrontal cortex, and } \\
\text { mediotemporal-striatal functional connectivity during } \\
\text { verbal paired associate learning task }\end{array}$ & - & [219] \\
\hline $\begin{array}{l}\text { Patients at clinical high } \\
\text { risk (CHR) of psychosis }\end{array}$ & $\begin{array}{l}\text { Double-blind, } \\
\text { randomized, } \\
\text { placebo-controlled }\end{array}$ & $\begin{array}{c}52 \\
\text { Antipsychotic medication-naive } \\
\text { participants at } C H R \text { of psychosis } \mathrm{N}=33 \\
\text { (CBD group } \mathrm{N}=16(10 \mathrm{M} / 6 \mathrm{~F}) \\
\text { Placebo group } \mathrm{N}=17(7 \mathrm{M} / 10 \mathrm{~F}) \\
\text { Healthy controls } \mathrm{N}=19(11 \mathrm{M} / 8 \mathrm{~F})\end{array}$ & $\begin{array}{l}600 \mathrm{mg} \text {; gelatin } \\
\text { capsules; p.o.; acute }\end{array}$ & $\begin{array}{l}\text { Improved right caudate, parahippocampal gyrus and } \\
\text { midbrain region's activation during verbal learning task }\end{array}$ & - & [220] \\
\hline $\begin{array}{l}\text { Patients at CHR } \\
\text { of psychosis }\end{array}$ & $\begin{array}{l}\text { Double-blind, } \\
\text { randomized, } \\
\text { placebo-controlled }\end{array}$ & 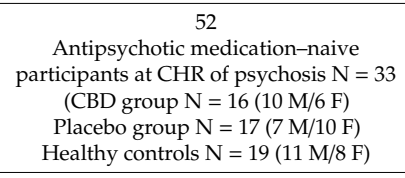 & $\begin{array}{l}600 \mathrm{mg} \text {; gelatin } \\
\text { capsules; p.o.; acute }\end{array}$ & $\begin{array}{l}\text { Attenuated the increased activation in left insula/parietal } \\
\text { operculum, and reduced reaction time during monetary } \\
\text { incentive delay task }\end{array}$ & - & [221] \\
\hline Schizophrenia & $\begin{array}{l}\text { Double-blind } \\
\text { randomized, } \\
\text { placebo-controlled }\end{array}$ & $\begin{array}{c}28 \\
\text { CBD 600 mg group } \mathrm{N}=9(5 \mathrm{M} / 4 \mathrm{~F}) \\
\text { CBD 300mg group } \mathrm{N}=9(6 \mathrm{M} / 3 \mathrm{~F}) \\
\text { Placebo group } \mathrm{N}=10(7 \mathrm{M} / 3 \mathrm{~F})\end{array}$ & $\begin{array}{l}300 \text { or } 600 \mathrm{mg} \text {; gelatin } \\
\text { capsules; p.o.; acute }\end{array}$ & $\begin{array}{l}\text { No effects were observed in SCWT and } \\
\text { electrodermal responsiveness }\end{array}$ & - & [222] \\
\hline
\end{tabular}

BACS: Brief Assessment of Cognition in Schizophrenia; CBD: cannabidiol; GAF: Global Assessment of Functioning; CHR: clinical high risk; GI: gastrointestinal; MCCB: MATRICS Consensus Cognitive Battery; PANSS: MATRICS Consensus Cognitive Battery; p.o.: orally; SCWT: Stroop Color and Word Test. $\downarrow$ decrease; $\uparrow$ increase. 
In the second clinical study, a multicenter randomized controlled trial, CBD significantly improved positive psychotic symptoms (PANSS). There was also a tendency to increase cognitive performance (Brief Assessment of Cognition in Schizophrenia, BACS) and overall functioning (Global Assessment of Functioning, GAF). The administration of CBD did not modify prolactin concentrations in plasma, Simpson Angus Scale rating, weight, waist circumference, liver function, inflammatory markers, or HDL cholesterol levels-common harmful effects of current antipsychotic drugs. The prevalence of adverse events was similar in CBD- and placebo-treated patients, though there was a high proportion of mild gastrointestinal events in the CBD-treated group [218].

Similarly, in a double-blind, randomized clinical trial, CBD led to significant improvements on the PANSS scale, comparable to amisulpride, but with fewer extrapyramidal symptoms, less weight gain and a lower prolactin increase. Furthermore, CBD was well tolerated and did not significantly affect hepatic or cardiac functions. Therefore, the safety profile of CBD was better than the atypical antipsychotic amisulpride. There was also an increase in anandamide plasma concentrations in schizophrenic patients treated with CBD, highlighting this as a potential mechanism of action underlying the effects of CBD [201].

Additional clinical studies using functional magnetic resonance imaging (fMRI) showed that a single dose of CBD attenuated the reduced activity found in the mediotemporal, prefrontal and striatal brain regions of schizophrenic patients while performing verbal paired learning tasks. CBD also attenuated hippocampal-striatal functional connectivity in these patients compared to healthy controls [219]. Neuroimaging studies have also used the fMRI technique in antipsychotic-naïve patients at clinical high risk for psychosis during a verbal learning [220] or a monetary incentive delay task [221]. In the verbal learning task, a single dose of CBD improved the activation in the right caudate and in the parahippocampal gyrus and midbrain during encoding and recall, respectively [220]. In addition, CBD attenuated the hyperactivation of the left insula/parietal operculum and normalized the reaction time in the monetary incentive delay task [221]. However, CBD did not improve selective attention in schizophrenic patients, assessed by the Stroop Color Word Test. Despite these results, authors did not discard a possible beneficial effect after the chronic administration of CBD [222].

Currently, three ongoing clinical trials (NCT03883360 [223]; NCT02926859 [224]; NCT04411225 [225]) are assessing the efficacy of CBD versus placebo or olanzapine in psychosis and SCZ. The results of these clinical trials should be available in the next few years, providing evidence about the potential usefulness of $\mathrm{CBD}$ in psychotic disorders.

In summary, although the clinical studies are heterogeneous, the results found suggest the potential of CBD as monotherapy or as an adjunctive treatment for SCZ. However, more double-blind, placebo-controlled clinical trials are needed to evaluate effectiveness and clarify its profile of side effects.

\section{Summary and Conclusions}

Our results suggest that CBD may be a potential therapy for treating anxiety, depression, schizophrenia, and related psychotic disorders. Overall, animal models showed that the administration of CBD minimizes anxiety, depression, and stress-related behaviors. Some negative results were also found, suggesting that the anxiolytic and antidepressant properties of CBD depend on the species/strain, age, gender, doses, route of administration and time course (acute vs. chronic). Similarly, in schizophrenia and related psychotic disorders, a variety of animal models show that CBD is effective for modulating hyperactivity and PPI alterations, with a pharmacological profile similar to atypical antipsychotics [154] and the involvement of various mechanisms.

One peculiarity of CBD is its multifactorial molecular profile, acting on more than 65 targets, including the $5-\mathrm{HT}_{1 \mathrm{~A}}$ receptor, the $\mathrm{G}$ protein-coupled receptor 55 (GPR55), cannabinoids receptors $\left(\mathrm{CB}_{1} \mathrm{r}\right.$ and $\left.\mathrm{CB}_{2} \mathrm{r}\right)$, opioid receptors $(\delta$ and $\mu)$, transient receptor potential vanilloid 1 (TRPV1), and others (for a review, see $[39,64,226]$ ). This hampers the identification of the neurobiological mechanisms by which CBD induces its behavioral effects. However, the cumulative data obtained suggest that certain targets appear to play a more relevant role than others in the anxiolytic, antidepressant and 
antipsychotic effects of CBD, depending on the animal model used. For example, the $5-\mathrm{HT}_{1 \mathrm{~A}}$ receptor plays a significant role in the anxiolytic action of CBD in some studies, but in others, using different experimental conditions, $\mathrm{CB}_{1} \mathrm{r}$ seems to be the most closely involved target. Despite these discrepancies, there are enough reports to conclude that both receptors, along with additional elements crucial in emotional responses and cognitive processing, such as the HPA axis, anandamide, cannabinoid $\mathrm{CB}_{2} \mathrm{r}$, neurogenesis factors and $\mathrm{GABA}_{\mathrm{A}}$ receptors, are involved, directly or indirectly, on the actions induced by $\mathrm{CBD}$ on these diseases (Figure 1). Further studies are needed to fully elucidate the mechanisms of action underlying CBD's anxiolytic, antidepressant and antipsychotic-like effects, for example, evaluating the role of GPR55, since CBD appears to act as an antagonist of this receptor [72,73], and additional evidence supports its involvement in anxiety $[227,228]$.

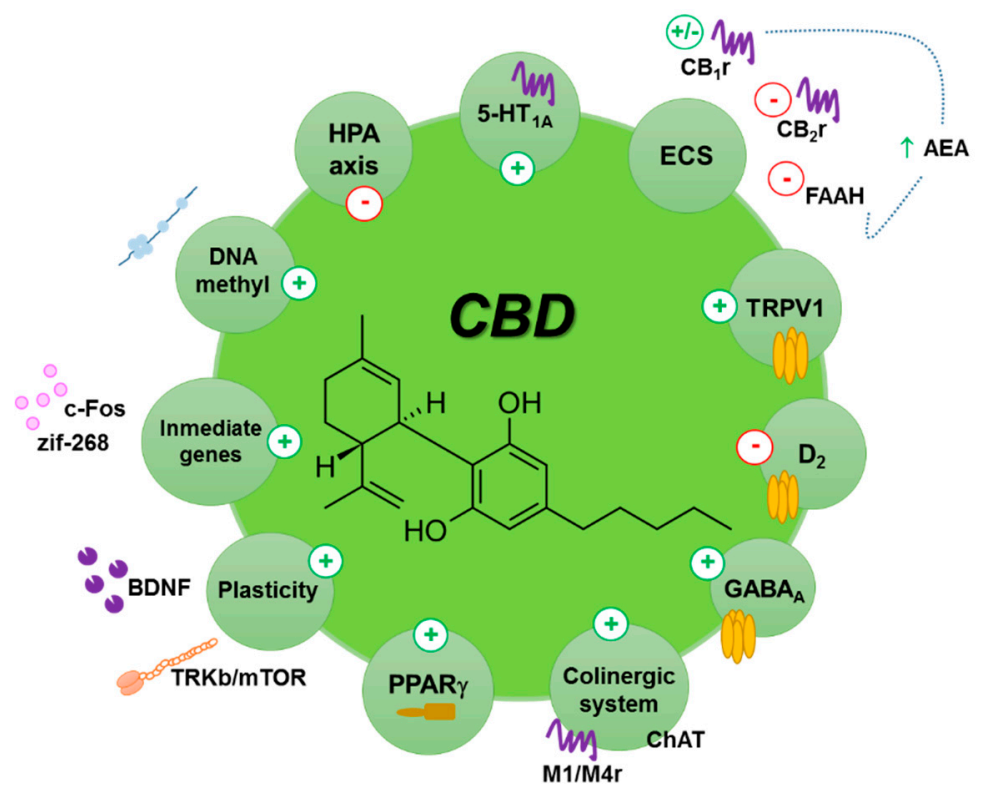

Figure 1. Schematic representation of the main hypothesized mechanisms described for the anxiolytic, antidepressant and antipsychotic actions of CBD. AEA: anandamide; $5-\mathrm{HT}_{1 \mathrm{~A}}$ : serotonin receptor $1 \mathrm{~A}$; BDNF: brain delivered neurotrophic factor; $\mathrm{CB}_{1}$ r: cannabinoid $\mathrm{CB} 1$ receptor; $\mathrm{CB}_{2} \mathrm{r}$ : cannabinoid $\mathrm{CB} 2$ receptor; ChAT: choline acetyltransferase; D2: dopamine receptor D2; DNA methyl: DNA methylation; ECS: endocannabinoid system; FAAH: fatty acid amide hydrolase; HPA axis: hypothalamus pituitary -axis; M1/M4r: muscarinic receptor 1 and 4; PPAR $\gamma$ : peroxisome proliferator activated receptor gamma; $\mathrm{TRKb} / \mathrm{mTOR}$ : tropomyosin-receptor-kinase $\mathrm{B} /$ mammalian target of rapamycin; TRPV1: transient receptor potential cation channel subfamily $\mathrm{V}$ member 1.

In humans, most studies have evaluated the anxiolytic-like actions of CBD in healthy volunteers or in patients with anxiety secondary to another clinical condition, such as drug use disorders. Few studies have included patients diagnosed with anxiety disorders. Besides, the small number of patients included in these studies precludes definitive conclusions. A similar scenario occurs with PTSD, where preliminary (but small) clinical trials suggest that CBD reduces PSTD severity. In the case of depressive disorders, there is a dearth of studies evaluating the effects of CBD. The efficacy of CBD for reducing depressive symptoms has only been assessed in patients with chronic pain or in cannabis users, with positive results. In the case of SCZ, a larger body of evidence suggests the possible usefulness of CBD as monotherapy or adjunctive treatment. All of the clinical trials carried out indicate that CBD is well tolerated, with no extrapyramidal side effects, less weight gain, and lower prolactin increases than current antipsychotic drugs. Thus, these results suggest that CBD presents an interesting risk-benefit profile that deserves further exploration in large clinical trials, for example, in patients of different ages, in order to ensure its safety in children and the elderly. 
All of the presented results show that CBD plays a significant role in the regulation of anxiety- and depressive-related behaviors, cognition, and locomotion. However, it is necessary to develop additional, larger animal and human studies to definitively characterize the usefulness, safety, and efficacy of CBD for these psychiatric disorders. Ongoing double-blind studies, expected to finish in the next few years, will be essential to determine whether CBD is truly an option to improve the pharmacological management of these type of psychiatric patients.

Author Contributions: M.S.G.-G. and J.M. conceived the presented idea. M.S.G.-G. took the lead in writing the manuscript. F.N., A.G., A.A.-O. and F.S. contributed in writing the manuscript in consultation with M.S.G.-G. All authors provided critical feedback and helped shape the research, analysis, and manuscript. All authors have read and agreed to the published version of the manuscript.

Funding: This research received no external funding.

Acknowledgments: We thank all participants in this study.

Conflicts of Interest: The authors declare no conflict of interest.

\section{References}

1. World Health Organization. Depression in Europe: Facts and Figures. Available online: https://www.euro.who.int/en/health-topics/noncommunicable-diseases/mental-health/news/news/ 2012/10/depression-in-europe/depression-in-europe-facts-and-figures (accessed on 19 November 2020).

2. Whiteford, H.; Ferrari, A.J.; Degenhardt, L.; Feigin, V.; Vos, T. Chapter 2 Global burden of mental, neurological and substance use disorder: An analysis from the global burden of disease study 2010. In Mental, Neurological, and Substance Use Disorders: Disease Control Priorities, 3rd ed.; Patel, V., Laxminarayan, R., Medina-Mora, M.L., Dua, T., Chisholm, D., Eds.; The International Bank for Reconstruction and Development: Washington, DC, USA, 2016; Volume 4.

3. World Health Organization. Mental Health Policies and Programmes in the Workplace; World Health Organization: Geneva, Switzerland, 2005.

4. Dome, P.; Rihmer, Z.; Gonda, X. Suicide Risk in Bipolar Disorder: A Brief Review. Medicina 2019, 55, 403. [CrossRef] [PubMed]

5. Arsenault-Lapierre, G.; Kim, C.; Turecki, G. Psychiatric diagnoses in 3275 suicides: A meta-analysis. BMC Psychiatry 2004, 4, 37. [CrossRef] [PubMed]

6. Cavanagh, J.T.; Carson, A.J.; Sharpe, M.; Lawrie, S.M. Psychological autopsy studies of suicide: A systematic review. Psychol. Med. 2003, 33, 395-405. [CrossRef] [PubMed]

7. World Health Organization. The WHO Special Initiative for Mental Health (2019-2023): Universal Health Coverage for Mental Health; World Health Organization: Geneva, Switzerland, 2019.

8. Newson, J.J.; Hunter, D.; Thiagarajan, T.C. The Heterogeneity of Mental Health Assessment. Front. Psychiatry 2020, 11, 76. [CrossRef]

9. Maroney, M. An update on current treatment strategies and emerging agents for the management of schizophrenia. Am. J. Manag. Care 2020, 26, S55-S61. [CrossRef]

10. Blumberg, M.J.; Vaccarino, S.R.; McInerney, S.J. Procognitive Effects of Antidepressants and Other Therapeutic Agents in Major Depressive Disorder: A Systematic Review. J. Clin. Psychiatry 2020, 81. [CrossRef]

11. Chen, C.; Shan, W. Pharmacological and non-pharmacological treatments for major depressive disorder in adults: A systematic review and network meta-analysis. Psychiatry Res. 2019, 281, 112595. [CrossRef]

12. Machado-Vieira, R. Tracking the impact of translational research in psychiatry: State of the art and perspectives. J. Transl. Med. 2012, 10, 175. [CrossRef]

13. Li, C.T.; Yang, K.C.; Lin, W.C. Glutamatergic Dysfunction and Glutamatergic Compounds for Major Psychiatric Disorders: Evidence From Clinical Neuroimaging Studies. Front. Psychiatry 2018, 9, 767. [CrossRef]

14. Averill, L.A.; Purohit, P.; Averill, C.L.; Boesl, M.A.; Krystal, J.H.; Abdallah, C.G. Glutamate dysregulation and glutamatergic therapeutics for PTSD: Evidence from human studies. Neurosci. Lett. 2017, 649, 147-155. [CrossRef] 
15. Reus, G.Z.; de Moura, A.B.; Silva, R.H.; Resende, W.R.; Quevedo, J. Resilience Dysregulation in Major Depressive Disorder: Focus on Glutamatergic Imbalance and Microglial Activation. Curr. Neuropharmacol. 2018, 16, 297-307. [CrossRef] [PubMed]

16. Fogaca, M.V.; Duman, R.S. Cortical GABAergic Dysfunction in Stress and Depression: New Insights for Therapeutic Interventions. Front. Cell. Neurosci. 2019, 13, 87. [CrossRef] [PubMed]

17. Luscher, B.; Shen, Q.; Sahir, N. The GABAergic deficit hypothesis of major depressive disorder. Mol. Psychiatry 2011, 16, 383-406. [CrossRef] [PubMed]

18. de Jonge, J.C.; Vinkers, C.H.; Hulshoff Pol, H.E.; Marsman, A. GABAergic Mechanisms in Schizophrenia: Linking Postmortem and In Vivo Studies. Front. Psychiatry 2017, 8, 118. [CrossRef]

19. Saito, A.; Ballinger, M.D.; Pletnikov, M.V.; Wong, D.F.; Kamiya, A. Endocannabinoid system: Potential novel targets for treatment of schizophrenia. Neurobiol. Dis. 2013, 53, 10-17. [CrossRef]

20. Navarrete, F.; Garcia-Gutierrez, M.S.; Jurado-Barba, R.; Rubio, G.; Gasparyan, A.; Austrich-Olivares, A.; Manzanares, J. Endocannabinoid System Components as Potential Biomarkers in Psychiatry. Front. Psychiatry 2020, 11, 315. [CrossRef]

21. Sloan, M.E.; Grant, C.W.; Gowin, J.L.; Ramchandani, V.A.; Le Foll, B. Endocannabinoid signaling in psychiatric disorders: A review of positron emission tomography studies. Acta Pharmacol. Sin. 2019, 40, 342-350. [CrossRef]

22. Lee, T.T.; Hill, M.N.; Lee, F.S. Developmental regulation of fear learning and anxiety behavior by endocannabinoids. Genes Brain Behav. 2016, 15, 108-124. [CrossRef]

23. Daly, E.J.; Singh, J.B.; Fedgchin, M.; Cooper, K.; Lim, P.; Shelton, R.C.; Thase, M.E.; Winokur, A.; Van Nueten, L.; Manji, H.; et al. Efficacy and Safety of Intranasal Esketamine Adjunctive to Oral Antidepressant Therapy in Treatment-Resistant Depression: A Randomized Clinical Trial. JAMA Psychiatry 2018, 75, 139-148. [CrossRef]

24. Fedgchin, M.; Trivedi, M.; Daly, E.J.; Melkote, R.; Lane, R.; Lim, P.; Vitagliano, D.; Blier, P.; Fava, M.; Liebowitz, M.; et al. Efficacy and Safety of Fixed-Dose Esketamine Nasal Spray Combined With a New Oral Antidepressant in Treatment-Resistant Depression: Results of a Randomized, Double-Blind, Active-Controlled Study (TRANSFORM-1). Int. J. Neuropsychopharmacol. Off. Sci. J. Coll. Int. Neuropsychopharmacol. 2019, 22, 616-630. [CrossRef]

25. Daly, E.J.; Trivedi, M.H.; Janik, A.; Li, H.; Zhang, Y.; Li, X.; Lane, R.; Lim, P.; Duca, A.R.; Hough, D.; et al. Efficacy of Esketamine Nasal Spray Plus Oral Antidepressant Treatment for Relapse Prevention in Patients With Treatment-Resistant Depression: A Randomized Clinical Trial. JAMA Psychiatry 2019. [CrossRef] [PubMed]

26. Pertwee, R.G. The diverse CB1 and CB2 receptor pharmacology of three plant cannabinoids: delta9-tetrahydrocannabinol, cannabidiol and delta9-tetrahydrocannabivarin. Br. J. Pharmacol. 2008, 153, 199-215. [CrossRef] [PubMed]

27. Kinghorn, A.D.; Falk, H.; Gibbons, S.; Kobayashi, J. Phytocannbinoids: Unraveling the Complex Chemistry and Pharmacology of Cannabis Sativa; Springer International Publishing: Berlin/Heidelberg, Germany, 2017.

28. Gaoni, Y.; Mechoulam, R. Isolation, structure, and partial synthesis of an active constituent of hashish. J. Am. Chem. Soc. 1964, 86, 1646-1647. [CrossRef]

29. Adams, R.; Hunt, M.; Clark, J.H. Structure of cannabidiol, a product isolated from the Marihuana extract of Minnesota Wild Hemp. I. J. Am. Chem. Soc. 1940, 62, 196-200. [CrossRef]

30. Mechoulam, R.; Shvo, Y.; Hashish, I. The structure of cannabidiol. Tetrahedron 1963, 19, 2073-2078. [CrossRef]

31. Burstein, S. Cannabidiol (CBD) and its analogs: A review of their effects on inflammation. Bioorg. Med. Chem. 2015, 23, 1377-1385. [CrossRef]

32. Zlebnik, N.E.; Cheer, J.F. Beyond the CB1 Receptor: Is Cannabidiol the Answer for Disorders of Motivation? Annu. Rev. Neurosci. 2016, 39, 1-17. [CrossRef] [PubMed]

33. Fusar-Poli, P.; Crippa, J.A.; Bhattacharyya, S.; Borgwardt, S.J.; Allen, P.; Martin-Santos, R.; Seal, M.; Surguladze, S.A.; O'Carrol, C.; Atakan, Z.; et al. Distinct effects of \{delta\}9-tetrahydrocannabinol and cannabidiol on neural activation during emotional processing. Arch. Gen. Psychiatry 2009, 66, 95-105. [CrossRef]

34. Winton-Brown, T.T.; Allen, P.; Bhattacharyya, S.; Borgwardt, S.J.; Fusar-Poli, P.; Crippa, J.A.; Seal, M.L.; Martin-Santos, R.; Ffytche, D.; Zuardi, A.W.; et al. Modulation of auditory and visual processing by delta-9-tetrahydrocannabinol and cannabidiol: An FMRI study. Neuropsychopharmacology 2011, 36, 1340-1348. [CrossRef] 
35. Martin-Santos, R.; Crippa, J.A.; Batalla, A.; Bhattacharyya, S.; Atakan, Z.; Borgwardt, S.; Allen, P.; Seal, M.; Langohr, K.; Farre, M.; et al. Acute effects of a single, oral dose of d9-tetrahydrocannabinol (THC) and cannabidiol (CBD) administration in healthy volunteers. Curr. Pharm. Des. 2012, 18, 4966-4979. [CrossRef]

36. Parker, L.A.; Burton, P.; Sorge, R.E.; Yakiwchuk, C.; Mechoulam, R. Effect of low doses of delta9-tetrahydrocannabinol and cannabidiol on the extinction of cocaine-induced and amphetamine-induced conditioned place preference learning in rats. Psychopharmacology 2004, 175, 360-366. [CrossRef] [PubMed]

37. Vann, R.E.; Gamage, T.F.; Warner, J.A.; Marshall, E.M.; Taylor, N.L.; Martin, B.R.; Wiley, J.L. Divergent effects of cannabidiol on the discriminative stimulus and place conditioning effects of Delta(9)-tetrahydrocannabinol. Drug Alcohol Depend. 2008, 94, 191-198. [CrossRef] [PubMed]

38. Viudez-Martinez, A.; Garcia-Gutierrez, M.S.; Medrano-Relinque, J.; Navarron, C.M.; Navarrete, F.; Manzanares, J. Cannabidiol does not display drug abuse potential in mice behavior. Acta Pharmacol. Sin. 2019, 40, 358-364. [CrossRef] [PubMed]

39. Pisanti, S.; Malfitano, A.M.; Ciaglia, E.; Lamberti, A.; Ranieri, R.; Cuomo, G.; Abate, M.; Faggiana, G.; Proto, M.C.; Fiore, D.; et al. Cannabidiol: State of the art and new challenges for therapeutic applications. Pharmacol. Ther. 2017, 175, 133-150. [CrossRef] [PubMed]

40. Aviello, G.; Romano, B.; Borrelli, F.; Capasso, R.; Gallo, L.; Piscitelli, F.; Di Marzo, V.; Izzo, A.A. Chemopreventive effect of the non-psychotropic phytocannabinoid cannabidiol on experimental colon cancer. J. Mol. Med. 2012, 90, 925-934. [CrossRef]

41. El-Remessy, A.B.; Al-Shabrawey, M.; Khalifa, Y.; Tsai, N.T.; Caldwell, R.B.; Liou, G.I. Neuroprotective and blood-retinal barrier-preserving effects of cannabidiol in experimental diabetes. Am. J. Pathol. 2006, 168, 235-244. [CrossRef]

42. Karmaus, P.W.; Wagner, J.G.; Harkema, J.R.; Kaminski, N.E.; Kaplan, B.L. Cannabidiol (CBD) enhances lipopolysaccharide (LPS)-induced pulmonary inflammation in C57BL/6 mice. J. Immunotoxicol. 2013, 10, 321-328. [CrossRef]

43. Syed, Y.Y.; McKeage, K.; Scott, L.J. Delta-9-tetrahydrocannabinol/cannabidiol (Sativex(R)): A review of its use in patients with moderate to severe spasticity due to multiple sclerosis. Drugs 2014, 74, 563-578. [CrossRef]

44. Devinsky, O.; Patel, A.D.; Cross, J.H.; Villanueva, V.; Wirrell, E.C.; Privitera, M.; Greenwood, S.M.; Roberts, C.; Checketts, D.; VanLandingham, K.E.; et al. Effect of Cannabidiol on Drop Seizures in the Lennox-Gastaut Syndrome. N. Engl. J. Med. 2018, 378, 1888-1897. [CrossRef]

45. Martin-Moreno, A.M.; Reigada, D.; Ramirez, B.G.; Mechoulam, R.; Innamorato, N.; Cuadrado, A.; de Ceballos, M.L. Cannabidiol and other cannabinoids reduce microglial activation in vitro and in vivo: Relevance to Alzheimer's disease. Mol. Pharm. 2011, 79, 964-973. [CrossRef]

46. Iuvone, T.; Esposito, G.; De Filippis, D.; Scuderi, C.; Steardo, L. Cannabidiol: A promising drug for neurodegenerative disorders? CNS Neurosci. Ther. 2009, 15, 65-75. [CrossRef] [PubMed]

47. Kozela, E.; Lev, N.; Kaushansky, N.; Eilam, R.; Rimmerman, N.; Levy, R.; Ben-Nun, A.; Juknat, A.; Vogel, Z. Cannabidiol inhibits pathogenic $\mathrm{T}$ cells, decreases spinal microglial activation and ameliorates multiple sclerosis-like disease in C57BL/6 mice. Br. J. Pharmacol. 2011, 163, 1507-1519. [CrossRef] [PubMed]

48. Perez, M.; Benitez, S.U.; Cartarozzi, L.P.; Del Bel, E.; Guimaraes, F.S.; Oliveira, A.L. Neuroprotection and reduction of glial reaction by cannabidiol treatment after sciatic nerve transection in neonatal rats. Eur. J. Neurosci. 2013, 38, 3424-3434. [CrossRef] [PubMed]

49. de Mello Schier, A.R.; de Oliveira Ribeiro, N.P.; Coutinho, D.S.; Machado, S.; Arias-Carrion, O.; Crippa, J.A.; Zuardi, A.W.; Nardi, A.E.; Silva, A.C. Antidepressant-like and anxiolytic-like effects of cannabidiol: A chemical compound of Cannabis sativa. CNS Neurol. Disord. Drug Targets 2014, 13, 953-960. [CrossRef]

50. Blessing, E.M.; Steenkamp, M.M.; Manzanares, J.; Marmar, C.R. Cannabidiol as a Potential Treatment for Anxiety Disorders. Neurother. J. Am. Soc. Exp. Neurother. 2015, 12, 825-836. [CrossRef]

51. Iseger, T.A.; Bossong, M.G. A systematic review of the antipsychotic properties of cannabidiol in humans. Schizophr. Res. 2015, 162, 153-161. [CrossRef]

52. Huestis, M.A. Pharmacokinetics and metabolism of the plant cannabinoids, delta9-tetrahydrocannabinol, cannabidiol and cannabinol. Handb. Exp. Pharm. 2005. [CrossRef]

53. Hawksworth, G.M.K. Metabolism and Pharmacokinetics of Cannabinoids; Pharmaceutical Press: London, UK, 2004.

54. Millar, S.A.; Stone, N.L.; Yates, A.S.; O'Sullivan, S.E. A Systematic Review on the Pharmacokinetics of Cannabidiol in Humans. Front, Pharm. 2018, 9, 1365. [CrossRef] 
55. Devinsky, O.; Cilio, M.R.; Cross, H.; Fernandez-Ruiz, J.; French, J.; Hill, C.; Katz, R.; Di Marzo, V.; Jutras-Aswad, D.; Notcutt, W.G.; et al. Cannabidiol: Pharmacology and potential therapeutic role in epilepsy and other neuropsychiatric disorders. Epilepsia 2014, 55, 791-802. [CrossRef]

56. Reddy, D.S. The Utility of Cannabidiol in the Treatment of Refractory Epilepsy. Clin. Pharm. 2017, 101, 182-184. [CrossRef]

57. Ohlsson, A.; Lindgren, J.E.; Andersson, S.; Agurell, S.; Gillespie, H.; Hollister, L.E. Single dose kinetics of cannabidiol in man. Cannabinoids Chem. Pharmacol. Ther. Asp. 1984, 219-225. [CrossRef]

58. Harvey, D.J.; Samara, E.; Mechoulam, R. Comparative metabolism of cannabidiol in dog, rat and man. Pharm. Biochem. Behav. 1991, 40, 523-532. [CrossRef]

59. Ujvary, I.; Hanus, L. Human Metabolites of Cannabidiol: A Review on Their Formation, Biological Activity, and Relevance in Therapy. Cannabis Cannabinoid Res. 2016, 1, 90-101. [CrossRef] [PubMed]

60. Jiang, R.; Yamaori, S.; Takeda, S.; Yamamoto, I.; Watanabe, K. Identification of cytochrome P450 enzymes responsible for metabolism of cannabidiol by human liver microsomes. Life Sci. 2011, 89, 165-170. [CrossRef]

61. Guy, G.W.; Robson, P.J. A Phase I, Open Label, Four-Way Crossover Study to Compare the Pharmacokinetic Profiles of a Single Dose of $20 \mathrm{mg}$ of a Cannabis Based Medicine Extract (CBME) Administered on 3 Different Areas of the Buccal Mucosa and to Investigate the Pharmacokinetics of CBME per Oral in Healthy Male and Female Volunteers (GWPK0112). J. Cannabis Ther. 2004, 3, 79-120. [CrossRef]

62. Bergamaschi, M.M.; Queiroz, R.H.; Zuardi, A.W.; Crippa, J.A. Safety and side effects of cannabidiol, a Cannabis sativa constituent. Curr. Drug Saf. 2011, 6, 237-249. [CrossRef]

63. Zuardi, A.W.; Morais, S.L.; Guimaraes, F.S.; Mechoulam, R. Antipsychotic effect of cannabidiol. J. Clin. Psychiatry 1995, 56, 485-486.

64. Ibeas Bih, C.; Chen, T.; Nunn, A.V.; Bazelot, M.; Dallas, M.; Whalley, B.J. Molecular Targets of Cannabidiol in Neurological Disorders. Neurother. J. Am. Soc. Exp. Neurother. 2015, 12, 699-730. [CrossRef]

65. Thomas, A.; Baillie, G.L.; Phillips, A.M.; Razdan, R.K.; Ross, R.A.; Pertwee, R.G. Cannabidiol displays unexpectedly high potency as an antagonist of CB1 and CB2 receptor agonists in vitro. Br. J. Pharmacol. 2007, 150, 613-623. [CrossRef]

66. Mechoulam, R.; Peters, M.; Murillo-Rodriguez, E.; Hanus, L.O. Cannabidiol-Recent advances. Chem. Biodivers. 2007, 4, 1678-1692. [CrossRef]

67. Izzo, A.A.; Borrelli, F.; Capasso, R.; Di Marzo, V.; Mechoulam, R. Non-psychotropic plant cannabinoids: New therapeutic opportunities from an ancient herb. Trends Pharmacol. Sci. 2009, 30, 515-527. [CrossRef] [PubMed]

68. McPartland, J.M.; Duncan, M.; Di Marzo, V.; Pertwee, R.G. Are cannabidiol and Delta(9) -tetrahydrocannabivarin negative modulators of the endocannabinoid system? A systematic review. Br. J. Pharmacol. 2015, 172, 737-753. [CrossRef] [PubMed]

69. Laprairie, R.B.; Bagher, A.M.; Kelly, M.E.; Denovan-Wright, E.M. Cannabidiol is a negative allosteric modulator of the cannabinoid CB1 receptor. Br. J. Pharmacol. 2015, 172, 4790-4805. [CrossRef] [PubMed]

70. Stern, C.A.J.; da Silva, T.R.; Raymundi, A.M.; de Souza, C.P.; Hiroaki-Sato, V.A.; Kato, L.; Guimaraes, F.S.; Andreatini, R.; Takahashi, R.N.; Bertoglio, L.J. Cannabidiol disrupts the consolidation of specific and generalized fear memories via dorsal hippocampus CB1 and CB2 receptors. Neuropharmacology 2017, 125, 220-230. [CrossRef] [PubMed]

71. De Petrocellis, L.; Ligresti, A.; Moriello, A.S.; Allara, M.; Bisogno, T.; Petrosino, S.; Stott, C.G.; Di Marzo, V. Effects of cannabinoids and cannabinoid-enriched Cannabis extracts on TRP channels and endocannabinoid metabolic enzymes. Br. J. Pharmacol. 2011, 163, 1479-1494. [CrossRef]

72. Whyte, L.S.; Ryberg, E.; Sims, N.A.; Ridge, S.A.; Mackie, K.; Greasley, P.J.; Ross, R.A.; Rogers, M.J. The putative cannabinoid receptor GPR55 affects osteoclast function in vitro and bone mass in vivo. Proc. Natl. Acad. Sci. USA 2009, 106, 16511-16516. [CrossRef]

73. Sylantyev, S.; Jensen, T.P.; Ross, R.A.; Rusakov, D.A. Cannabinoid- and lysophosphatidylinositol-sensitive receptor GPR55 boosts neurotransmitter release at central synapses. Proc. Natl. Acad. Sci. USA 2013, 110, 5193-5198. [CrossRef]

74. Sylantyev, S.J.T.; Ross, R.A.; Rusakov, D.A. The enigmatic receptor GPR55 potentiates neurotransmitter release at central synapses. In Proceedings of the Neuroscience Meeting Planner Washington, DC: Society for Neuroscience Online: Program, Washington, DC, USA, 12-16 November 2011. Program 653.01, Poster B28. 
75. Poddar, M.K.; Dewey, W.L. Effects of cannabinoids on catecholamine uptake and release in hypothalamic and striatal synaptosomes. J. Pharmacol. Exp. Ther. 1980, 214, 63-67.

76. Pandolfo, P.; Silveirinha, V.; dos Santos-Rodrigues, A.; Venance, L.; Ledent, C.; Takahashi, R.N.; Cunha, R.A.; Kofalvi, A. Cannabinoids inhibit the synaptic uptake of adenosine and dopamine in the rat and mouse striatum. Eur. J. Pharm. 2011, 655, 38-45. [CrossRef]

77. Vaysse, P.J.; Gardner, E.L.; Zukin, R.S. Modulation of rat brain opioid receptors by cannabinoids. J. Pharmacol. Exp. Ther. 1987, 241, 534-539.

78. Kathmann, M.; Flau, K.; Redmer, A.; Trankle, C.; Schlicker, E. Cannabidiol is an allosteric modulator at muand delta-opioid receptors. Naunyn-Schmiedeberg's Arch. Pharmacol. 2006, 372, 354-361. [CrossRef] [PubMed]

79. Seeman, P. Cannabidiol is a partial agonist at dopamine D2High receptors, predicting its antipsychotic clinical dose. Transl. Psychiatry 2016, 6, e920. [CrossRef] [PubMed]

80. Rock, E.M.; Bolognini, D.; Limebeer, C.L.; Cascio, M.G.; Anavi-Goffer, S.; Fletcher, P.J.; Mechoulam, R.; Pertwee, R.G.; Parker, L.A. Cannabidiol, a non-psychotropic component of cannabis, attenuates vomiting and nausea-like behaviour via indirect agonism of 5-HT(1A) somatodendritic autoreceptors in the dorsal raphe nucleus. Br. J. Pharmacol. 2012, 165, 2620-2634. [CrossRef] [PubMed]

81. Russo, E.B.; Burnett, A.; Hall, B.; Parker, K.K. Agonistic properties of cannabidiol at 5-HT1a receptors. Neurochem. Res. 2005, 30,1037-1043. [CrossRef]

82. World Health Organization. Depression and Other Common Mental Disorders; WHO: Geneva, Switzerland, 2017.

83. Heather, A.; Church, A.C.; Lucey, J.V. Core Psychiatry, 3rd ed.; Elsevier: Amsterdam, The Netherlands, 2012. [CrossRef]

84. Rantala, M.J.; Luoto, S.; Krams, I.; Karlsson, H. Depression subtyping based on evolutionary psychiatry: Proximate mechanisms and ultimate functions. Brain Behav. Immun. 2018, 69, 603-617. [CrossRef]

85. Tolentino, J.C.; Schmidt, S.L. DSM-5 Criteria and Depression Severity: Implications for Clinical Practice. Front. Psychiatry 2018, 9, 450. [CrossRef]

86. Aragones, E.; Pinol, J.L.; Labad, A. Comorbidity of major depression with other common mental disorders in primary care patients. Aten Primaria 2009, 41, 545-551. [CrossRef]

87. Cole, J.; McGuffin, P.; Farmer, A.E. The classification of depression: Are we still confused? Br. J. Psychiatry 2008, 192, 83-85. [CrossRef]

88. Tiller, J.W. Depression and anxiety. Med. J. Aust. 2013, 199, S28-S31. [CrossRef]

89. Ogawa, Y.; Takeshima, N.; Hayasaka, Y.; Tajika, A.; Watanabe, N.; Streiner, D.; Furukawa, T.A. Antidepressants plus benzodiazepines for adults with major depression. Cochrane Database Syst. Rev. 2019, 6, CD001026. [CrossRef]

90. Howland, R.H. Buspirone: Back to the Future. J. Psychosoc. Nurs. Ment. Health Serv. 2015, 53, $21-24$. [CrossRef] [PubMed]

91. NHS Psychological Therapies Service. Generalized Anxiety Disorder in Adults-Treatment. Available online: https://www.nhs.uk/conditions/generalised-anxiety-disorder/treatment (accessed on 19 November 2020).

92. Machmutow, K.; Meister, R.; Jansen, A.; Kriston, L.; Watzke, B.; Harter, M.C.; Liebherz, S. Comparative effectiveness of continuation and maintenance treatments for persistent depressive disorder in adults. Cochrane Database Syst. Rev. 2019, 5, CD012855. [CrossRef] [PubMed]

93. Khan, A.; Faucett, J.; Lichtenberg, P.; Kirsch, I.; Brown, W.A. A systematic review of comparative efficacy of treatments and controls for depression. PLoS ONE 2012, 7, e41778. [CrossRef]

94. Barbato, A.; D'Avanzo, B.; Parabiaghi, A. Couple therapy for depression. Cochrane Database Syst. Rev. 2018, 6, CD004188. [CrossRef]

95. Filho, N.G.S.; Tufik, S. Comparative effects between cannabidiol and diazepam on neophobia, food intake and conflict behavior. Res. Commun. Psychol. Psychiatry Behav. 1981, 6, 251-266.

96. Zuardi, A.W.; Karniol, I.G. Effects on variable-interval performance in rats of delta 9-tetrahydrocannabinol and cannabidiol, separately and in combination. Braz. J. Med. Biol. Res. 1983, 16, 141-146. [PubMed]

97. Guimaraes, F.S.; Chiaretti, T.M.; Graeff, F.G.; Zuardi, A.W. Antianxiety effect of cannabidiol in the elevated plus-maze. Psychopharmacology 1990, 100, 558-559. [CrossRef]

98. Onaivi, E.S.; Green, M.R.; Martin, B.R. Pharmacological characterization of cannabinoids in the elevated plus maze. J. Pharmacol. Exp. Ther. 1990, 253, 1002-1009. 
99. Almeida, V.; Levin, R.; Peres, F.F.; Niigaki, S.T.; Calzavara, M.B.; Zuardi, A.W.; Hallak, J.E.; Crippa, J.A.; Abilio, V.C. Cannabidiol exhibits anxiolytic but not antipsychotic property evaluated in the social interaction test. Prog. Neuro-Psychopharmacol. Biol. Psychiatry 2013, 41, 30-35. [CrossRef]

100. Resstel, L.B.; Tavares, R.F.; Lisboa, S.F.; Joca, S.R.; Correa, F.M.; Guimaraes, F.S. 5-HT1A receptors are involved in the cannabidiol-induced attenuation of behavioural and cardiovascular responses to acute restraint stress in rats. Br. J. Pharmacol. 2009, 156, 181-188. [CrossRef]

101. Viudez-Martinez, A.; Garcia-Gutierrez, M.S.; Manzanares, J. Cannabidiol regulates the expression of hypothalamus-pituitary-adrenal axis-related genes in response to acute restraint stress. J. Psychopharmacol. 2018, 32, 1379-1384. [CrossRef] [PubMed]

102. Moreira, F.A.; Aguiar, D.C.; Guimaraes, F.S. Anxiolytic-like effect of cannabidiol in the rat Vogel conflict test. Prog. Neuro-Psychopharmacol. Biol. Psychiatry 2006, 30, 1466-1471. [CrossRef] [PubMed]

103. Nardo, M.; Casarotto, P.C.; Gomes, F.V.; Guimaraes, F.S. Cannabidiol reverses the mCPP-induced increase in marble-burying behavior. Fundam. Clin. Pharmacol. 2014, 28, 544-550. [CrossRef] [PubMed]

104. Casarotto, P.C.; Gomes, F.V.; Resstel, L.B.; Guimaraes, F.S. Cannabidiol inhibitory effect on marble-burying behaviour: Involvement of CB1 receptors. Behav. Pharm. 2010, 21, 353-358. [CrossRef]

105. Todd, S.M.; Arnold, J.C. Neural correlates of interactions between cannabidiol and Delta(9) -tetrahydrocannabinol in mice: Implications for medical cannabis. Br. J. Pharmacol. 2016, 173, 53-65. [CrossRef]

106. Todd, S.M.; Zhou, C.; Clarke, D.J.; Chohan, T.W.; Bahceci, D.; Arnold, J.C. Interactions between cannabidiol and Delta(9)-THC following acute and repeated dosing: Rebound hyperactivity, sensorimotor gating and epigenetic and neuroadaptive changes in the mesolimbic pathway. Eur. Neuropsychopharmacol. 2017, 27, 132-145. [CrossRef]

107. Sales, A.J.; Fogaca, M.V.; Sartim, A.G.; Pereira, V.S.; Wegener, G.; Guimaraes, F.S.; Joca, S.R.L. Cannabidiol Induces Rapid and Sustained Antidepressant-Like Effects Through Increased BDNF Signaling and Synaptogenesis in the Prefrontal Cortex. Mol. Neurobiol. 2019, 56, 1070-1081. [CrossRef]

108. Gall, Z.; Farkas, S.; Albert, A.; Ferencz, E.; Vancea, S.; Urkon, M.; Kolcsar, M. Effects of Chronic Cannabidiol Treatment in the Rat Chronic Unpredictable Mild Stress Model of Depression. Biomolecules 2020, 10, 801. [CrossRef]

109. Stern, C.A.; Gazarini, L.; Takahashi, R.N.; Guimaraes, F.S.; Bertoglio, L.J. On disruption of fear memory by reconsolidation blockade: Evidence from cannabidiol treatment. Neuropsychopharmacology 2012, 37, 2132-2142. [CrossRef]

110. Shbiro, L.; Hen-Shoval, D.; Hazut, N.; Rapps, K.; Dar, S.; Zalsman, G.; Mechoulam, R.; Weller, A.; Shoval, G. Effects of cannabidiol in males and females in two different rat models of depression. Physiol. Behav. 2019, 201,59-63. [CrossRef]

111. Reus, G.Z.; Stringari, R.B.; Ribeiro, K.F.; Luft, T.; Abelaira, H.M.; Fries, G.R.; Aguiar, B.W.; Kapczinski, F.; Hallak, J.E.; Zuardi, A.W.; et al. Administration of cannabidiol and imipramine induces antidepressant-like effects in the forced swimming test and increases brain-derived neurotrophic factor levels in the rat amygdala. Acta Neuropsychiatr. 2011, 23, 241-248. [CrossRef] [PubMed]

112. Campos, A.C.; Guimaraes, F.S. Involvement of 5HT1A receptors in the anxiolytic-like effects of cannabidiol injected into the dorsolateral periaqueductal gray of rats. Psychopharmacology 2008, 199, 223-230. [CrossRef] [PubMed]

113. de Paula Soares, V.; Campos, A.C.; Bortoli, V.C.; Zangrossi, H., Jr.; Guimaraes, F.S.; Zuardi, A.W. Intra-dorsal periaqueductal gray administration of cannabidiol blocks panic-like response by activating 5-HT1A receptors. Behav. Brain Res. 2010, 213, 225-229. [CrossRef] [PubMed]

114. Gomes, F.V.; Alves, F.H.; Guimaraes, F.S.; Correa, F.M.; Resstel, L.B.; Crestani, C.C. Cannabidiol administration into the bed nucleus of the stria terminalis alters cardiovascular responses induced by acute restraint stress through 5-HT(1)A receptor. Eur. Neuropsychopharmacol. 2013, 23, 1096-1104. [CrossRef]

115. Granjeiro, E.M.; Gomes, F.V.; Guimaraes, F.S.; Correa, F.M.; Resstel, L.B. Effects of intracisternal administration of cannabidiol on the cardiovascular and behavioral responses to acute restraint stress. Pharm. Biochem. Behav. 2011, 99, 743-748. [CrossRef]

116. Fogaca, M.V.; Campos, A.C.; Coelho, L.D.; Duman, R.S.; Guimaraes, F.S. The anxiolytic effects of cannabidiol in chronically stressed mice are mediated by the endocannabinoid system: Role of neurogenesis and dendritic remodeling. Neuropharmacology 2018, 135, 22-33. [CrossRef] 
117. Bitencourt, R.M.; Pamplona, F.A.; Takahashi, R.N. Facilitation of contextual fear memory extinction and anti-anxiogenic effects of AM404 and cannabidiol in conditioned rats. Eur. Neuropsychopharmacol. 2008, 18, 849-859. [CrossRef]

118. Lemos, J.I.; Resstel, L.B.; Guimaraes, F.S. Involvement of the prelimbic prefrontal cortex on cannabidiol-induced attenuation of contextual conditioned fear in rats. Behav. Brain Res. 2010, 207, 105-111. [CrossRef]

119. Do Monte, F.H.; Souza, R.R.; Bitencourt, R.M.; Kroon, J.A.; Takahashi, R.N. Infusion of cannabidiol into infralimbic cortex facilitates fear extinction via CB1 receptors. Behav. Brain Res. 2013, 250, 23-27. [CrossRef]

120. Raymundi, A.M.; da Silva, T.R.; Zampronio, A.R.; Guimaraes, F.S.; Bertoglio, L.J.; Stern, C.A.J. A time-dependent contribution of hippocampal CB1, CB2 and PPARgamma receptors to cannabidiol-induced disruption of fear memory consolidation. Br. J. Pharmacol. 2020, 177, 945-957. [CrossRef]

121. Sartim, A.G.; Guimaraes, F.S.; Joca, S.R. Antidepressant-like effect of cannabidiol injection into the ventral medial prefrontal cortex-Possible involvement of 5-HT1A and CB1 receptors. Behav. Brain Res. 2016, 303, 218-227. [CrossRef] [PubMed]

122. Bis-Humbert, C.; Garcia-Cabrerizo, R.; Garcia-Fuster, M.J. Decreased sensitivity in adolescent versus adult rats to the antidepressant-like effects of cannabidiol. Psychopharmacology 2020, 237, 1621-1631. [CrossRef] [PubMed]

123. ElBatsh, M.M.; Assareh, N.; Marsden, C.A.; Kendall, D.A. Anxiogenic-like effects of chronic cannabidiol administration in rats. Psychopharmacology 2012, 221, 239-247. [CrossRef] [PubMed]

124. Shoval, G.; Shbiro, L.; Hershkovitz, L.; Hazut, N.; Zalsman, G.; Mechoulam, R.; Weller, A. Prohedonic Effect of Cannabidiol in a Rat Model of Depression. Neuropsychobiology 2016, 73, 123-129. [CrossRef]

125. de Morais, H.; Chaves, Y.C.; Waltrick, A.P.F.; Jesus, C.H.A.; Genaro, K.; Crippa, J.A.; da Cunha, J.M.; Zanoveli, J.M. Sub-chronic treatment with cannabidiol but not with URB597 induced a mild antidepressant-like effect in diabetic rats. Neurosci. Lett. 2018, 682, 62-68. [CrossRef]

126. Long, L.E.; Chesworth, R.; Huang, X.F.; McGregor, I.S.; Arnold, J.C.; Karl, T. A behavioural comparison of acute and chronic Delta9-tetrahydrocannabinol and cannabidiol in C57BL/6JArc mice. Int. J. Neuropsychopharmacol. Off. Sci. J. Coll. Int. Neuropsychopharmacol. 2010, 13, 861-876. [CrossRef]

127. Assareh, N.; Gururajan, A.; Zhou, C.; Luo, J.L.; Kevin, R.C.; Arnold, J.C. Cannabidiol disrupts conditioned fear expression and cannabidiolic acid reduces trauma-induced anxiety-related behaviour in mice. Behav. Pharm. 2020, 31, 591-596. [CrossRef]

128. Kasten, C.R.; Zhang, Y.; Boehm, S.L., Jr. Acute Cannabinoids Produce Robust Anxiety-Like and Locomotor Effects in Mice, but Long-Term Consequences Are Age- and Sex-Dependent. Front. Behav. Neurosci. 2019, 13, 32. [CrossRef]

129. Gasparyan, A.N.F.; Manzanares, J. Effects of cannabidiol plus sertraline on behavioural and gene expression alterations in a long-lasting animal model of post-traumatic stress disorder. Authorea 2020. [CrossRef]

130. Schleicher, E.M.; Ott, F.W.; Muller, M.; Silcher, B.; Sichler, M.E.; Low, M.J.; Wagner, J.M.; Bouter, Y. Prolonged Cannabidiol Treatment Lacks on Detrimental Effects on Memory, Motor Performance and Anxiety in C57BL/6J Mice. Front. Behav. Neurosci. 2019, 13, 94. [CrossRef]

131. Wolf, S.A.; Bick-Sander, A.; Fabel, K.; Leal-Galicia, P.; Tauber, S.; Ramirez-Rodriguez, G.; Muller, A.; Melnik, A.; Waltinger, T.P.; Ullrich, O.; et al. Cannabinoid receptor CB1 mediates baseline and activity-induced survival of new neurons in adult hippocampal neurogenesis. Cell Commun. Signal 2010, 8, 12. [CrossRef] [PubMed]

132. Linge, R.; Jimenez-Sanchez, L.; Campa, L.; Pilar-Cuellar, F.; Vidal, R.; Pazos, A.; Adell, A.; Diaz, A. Cannabidiol induces rapid-acting antidepressant-like effects and enhances cortical 5-HT/glutamate neurotransmission: Role of 5-HT1A receptors. Neuropharmacology 2016, 103, 16-26. [CrossRef] [PubMed]

133. Schiavon, A.P.; Bonato, J.M.; Milani, H.; Guimaraes, F.S.; Weffort de Oliveira, R.M. Influence of single and repeated cannabidiol administration on emotional behavior and markers of cell proliferation and neurogenesis in non-stressed mice. Prog. Neuro-Psychopharmacol. Biol. Psychiatry 2016, 64, 27-34. [CrossRef] [PubMed]

134. Xu, C.; Chang, T.; Du, Y.; Yu, C.; Tan, X.; Li, X. Pharmacokinetics of oral and intravenous cannabidiol and its antidepressant-like effects in chronic mild stress mouse model. Env. Toxicol. Pharm. 2019, 70, 103202. [CrossRef] [PubMed]

135. Sales, A.J.; Guimaraes, F.S.; Joca, S.R.L. CBD modulates DNA methylation in the prefrontal cortex and hippocampus of mice exposed to forced swim. Behav. Brain Res. 2020, 388, 112627. [CrossRef] [PubMed] 
136. Sales, A.J.; Crestani, C.C.; Guimaraes, F.S.; Joca, S.R.L. Antidepressant-like effect induced by Cannabidiol is dependent on brain serotonin levels. Prog. Neuro-Psychopharmacol. Biol. Psychiatry 2018, 86, 255-261. [CrossRef] [PubMed]

137. Zanelati, T.V.; Biojone, C.; Moreira, F.A.; Guimaraes, F.S.; Joca, S.R. Antidepressant-like effects of cannabidiol in mice: Possible involvement of 5-HT1A receptors. Br. J. Pharmacol. 2010, 159, 122-128. [CrossRef]

138. El-Alfy, A.T.; Ivey, K.; Robinson, K.; Ahmed, S.; Radwan, M.; Slade, D.; Khan, I.; ElSohly, M.; Ross, S. Antidepressant-like effect of delta9-tetrahydrocannabinol and other cannabinoids isolated from Cannabis sativa L. Pharm. Biochem. Behav. 2010, 95, 434-442. [CrossRef]

139. Fogaca, M.V.; Reis, F.M.; Campos, A.C.; Guimaraes, F.S. Effects of intra-prelimbic prefrontal cortex injection of cannabidiol on anxiety-like behavior: Involvement of 5HT1A receptors and previous stressful experience. Eur. Neuropsychopharmacol. 2014, 24, 410-419. [CrossRef]

140. Resstel, L.B.; Joca, S.R.; Moreira, F.A.; Correa, F.M.; Guimaraes, F.S. Effects of cannabidiol and diazepam on behavioral and cardiovascular responses induced by contextual conditioned fear in rats. Behav. Brain Res. 2006, 172, 294-298. [CrossRef]

141. Rossignoli, M.T.; Lopes-Aguiar, C.; Ruggiero, R.N.; Do Val da Silva, R.A.; Bueno-Junior, L.S.; Kandratavicius, L.; Peixoto-Santos, J.E.; Crippa, J.A.; Cecilio Hallak, J.E.; Zuardi, A.W.; et al. Selective post-training time window for memory consolidation interference of cannabidiol into the prefrontal cortex: Reduced dopaminergic modulation and immediate gene expression in limbic circuits. Neuroscience 2017, 350, 85-93. [CrossRef] [PubMed]

142. Norris, C.; Loureiro, M.; Kramar, C.; Zunder, J.; Renard, J.; Rushlow, W.; Laviolette, S.R. Cannabidiol Modulates Fear Memory Formation Through Interactions with Serotonergic Transmission in the Mesolimbic System. Neuropsychopharmacology 2016, 41, 2839-2850. [CrossRef] [PubMed]

143. Marinho, A.L.; Vila-Verde, C.; Fogaca, M.V.; Guimaraes, F.S. Effects of intra-infralimbic prefrontal cortex injections of cannabidiol in the modulation of emotional behaviors in rats: Contribution of 5HT(1)A receptors and stressful experiences. Behav. Brain Res. 2015, 286, 49-56. [CrossRef] [PubMed]

144. Shallcross, J.; Hamor, P.; Bechard, A.R.; Romano, M.; Knackstedt, L.; Schwendt, M. The Divergent Effects of CDPPB and Cannabidiol on Fear Extinction and Anxiety in a Predator Scent Stress Model of PTSD in Rats. Front. Behav. Neurosci. 2019, 13, 91. [CrossRef]

145. Campos, A.C.; Ferreira, F.R.; Guimaraes, F.S. Cannabidiol blocks long-lasting behavioral consequences of predator threat stress: Possible involvement of 5HT1A receptors. J. Psychiatr. Res. 2012, 46, 1501-1510. [CrossRef]

146. Twardowschy, A.; Castiblanco-Urbina, M.A.; Uribe-Marino, A.; Biagioni, A.F.; Salgado-Rohner, C.J.; Crippa, J.A.; Coimbra, N.C. The role of 5-HT1A receptors in the anti-aversive effects of cannabidiol on panic attack-like behaviors evoked in the presence of the wild snake Epicrates cenchria crassus (Reptilia, Boidae). J. Psychopharmacol. 2013, 27, 1149-1159. [CrossRef]

147. Willner, P.; Muscat, R.; Papp, M. Chronic mild stress-induced anhedonia: A realistic animal model of depression. Neurosci. Biobehav. Rev. 1992, 16, 525-534. [CrossRef]

148. Willner, P. Validity, reliability and utility of the chronic mild stress model of depression: A 10-year review and evaluation. Psychopharmacology 1997, 134, 319-329. [CrossRef]

149. Campos, A.C.; Ortega, Z.; Palazuelos, J.; Fogaca, M.V.; Aguiar, D.C.; Diaz-Alonso, J.; Ortega-Gutierrez, S.; Vazquez-Villa, H.; Moreira, F.A.; Guzman, M.; et al. The anxiolytic effect of cannabidiol on chronically stressed mice depends on hippocampal neurogenesis: Involvement of the endocannabinoid system. Int. J. Neuropsychopharmacol. Off. Sci. J. Coll. Int. Neuropsychopharmacol. 2013, 16, 1407-1419. [CrossRef]

150. Karniol, I.G.; Shirakawa, I.; Kasinski, N.; Pfeferman, A.; Carlini, E.A. Cannabidiol interferes with the effects of delta 9 - tetrahydrocannabinol in man. Eur. J. Pharm. 1974, 28, 172-177. [CrossRef]

151. Zuardi, A.W.; Shirakawa, I.; Finkelfarb, E.; Karniol, I.G. Action of cannabidiol on the anxiety and other effects produced by delta 9-THC in normal subjects. Psychopharmacology 1982, 76, 245-250. [CrossRef] [PubMed]

152. Zuardi, A.W.; Cosme, R.A.; Graeff, F.G.; Guimaraes, F.S. Effects of ipsapirone and cannabidiol on human experimental anxiety. J. Psychopharmacol. 1993, 7, 82-88. [CrossRef] [PubMed]

153. Crippa, J.A.; Zuardi, A.W.; Garrido, G.E.; Wichert-Ana, L.; Guarnieri, R.; Ferrari, L.; Azevedo-Marques, P.M.; Hallak, J.E.; McGuire, P.K.; Filho Busatto, G. Effects of cannabidiol (CBD) on regional cerebral blood flow. Neuropsychopharmacology 2004, 29, 417-426. [CrossRef] [PubMed] 
154. Bhattacharyya, S.; Fusar-Poli, P.; Borgwardt, S.; Martin-Santos, R.; Nosarti, C.; O'Carroll, C.; Allen, P.; Seal, M.L.; Fletcher, P.C.; Crippa, J.A.; et al. Modulation of mediotemporal and ventrostriatal function in humans by Delta9-tetrahydrocannabinol: A neural basis for the effects of Cannabis sativa on learning and psychosis. Arch. Gen. Psychiatry 2009, 66, 442-451. [CrossRef] [PubMed]

155. Crippa, J.A.; Derenusson, G.N.; Ferrari, T.B.; Wichert-Ana, L.; Duran, F.L.; Martin-Santos, R.; Simoes, M.V.; Bhattacharyya, S.; Fusar-Poli, P.; Atakan, Z.; et al. Neural basis of anxiolytic effects of cannabidiol (CBD) in generalized social anxiety disorder: A preliminary report. J. Psychopharmacol. 2011, 25, 121-130. [CrossRef] [PubMed]

156. Bergamaschi, M.M.; Queiroz, R.H.; Chagas, M.H.; de Oliveira, D.C.; De Martinis, B.S.; Kapczinski, F.; Quevedo, J.; Roesler, R.; Schroder, N.; Nardi, A.E.; et al. Cannabidiol reduces the anxiety induced by simulated public speaking in treatment-naive social phobia patients. Neuropsychopharmacology 2011, 36, 1219-1226. [CrossRef] [PubMed]

157. Shannon, S.; Lewis, N.; Lee, H.; Hughes, S. Cannabidiol in Anxiety and Sleep: A Large Case Series. Perm. J. 2019, 23, 18-041. [CrossRef]

158. Hundal, H.; Lister, R.; Evans, N.; Antley, A.; Englund, A.; Murray, R.M.; Freeman, D.; Morrison, P.D. The effects of cannabidiol on persecutory ideation and anxiety in a high trait paranoid group. J. Psychopharmacol. 2018, 32, 276-282. [CrossRef]

159. Allsop, D.J.; Copeland, J.; Lintzeris, N.; Dunlop, A.J.; Montebello, M.; Sadler, C.; Rivas, G.R.; Holland, R.M.; Muhleisen, P.; Norberg, M.M.; et al. Nabiximols as an agonist replacement therapy during cannabis withdrawal: A randomized clinical trial. JAMA Psychiatry 2014, 71, 281-291. [CrossRef]

160. Hindocha, C.; Freeman, T.P.; Schafer, G.; Gardener, C.; Das, R.K.; Morgan, C.J.; Curran, H.V. Acute effects of delta-9-tetrahydrocannabinol, cannabidiol and their combination on facial emotion recognition: A randomised, double-blind, placebo-controlled study in cannabis users. Eur. Neuropsychopharmacol. 2015, 25, 325-334. [CrossRef]

161. Hurd, Y.L.; Spriggs, S.; Alishayev, J.; Winkel, G.; Gurgov, K.; Kudrich, C.; Oprescu, A.M.; Salsitz, E. Cannabidiol for the Reduction of Cue-Induced Craving and Anxiety in Drug-Abstinent Individuals With Heroin Use Disorder: A Double-Blind Randomized Placebo-Controlled Trial. Am. J. Psychiatry 2019, 176, 911-922. [CrossRef] [PubMed]

162. Fusar-Poli, P.; Allen, P.; Bhattacharyya, S.; Crippa, J.A.; Mechelli, A.; Borgwardt, S.; Martin-Santos, R.; Seal, M.L.; O'Carrol, C.; Atakan, Z.; et al. Modulation of effective connectivity during emotional processing by Delta 9-tetrahydrocannabinol and cannabidiol. Int. J. Neuropsychopharmacol. Off. Sci. J. Coll. Int. Neuropsychopharmacol. 2010, 13, 421-432. [CrossRef]

163. Elms, L.; Shannon, S.; Hughes, S.; Lewis, N. Cannabidiol in the Treatment of Post-Traumatic Stress Disorder: A Case Series. J. Altern. Complement Med. 2019, 25, 392-397. [CrossRef] [PubMed]

164. Beale, C.; Broyd, S.J.; Chye, Y.; Suo, C.; Schira, M.; Galettis, P.; Martin, J.H.; Yucel, M.; Solowij, N. Prolonged Cannabidiol Treatment Effects on Hippocampal Subfield Volumes in Current Cannabis Users. Cannabis Cannabinoid Res. 2018, 3, 94-107. [CrossRef] [PubMed]

165. Solowij, N.; Broyd, S.J.; Beale, C.; Prick, J.A.; Greenwood, L.M.; van Hell, H.; Suo, C.; Galettis, P.; Pai, N.; Fu, S.; et al. Therapeutic Effects of Prolonged Cannabidiol Treatment on Psychological Symptoms and Cognitive Function in Regular Cannabis Users: A Pragmatic Open-Label Clinical Trial. Cannabis Cannabinoid Res. 2018, 3, 21-34. [CrossRef]

166. Crippa, J.A.; Hallak, J.E.; Machado-de-Sousa, J.P.; Queiroz, R.H.; Bergamaschi, M.; Chagas, M.H.; Zuardi, A.W. Cannabidiol for the treatment of cannabis withdrawal syndrome: A case report. J. Clin. Pharm. Ther. 2013, 38, 162-164. [CrossRef]

167. Gruber, S. NCT02548559. Sublingual Cannabidiol for Anxiety. Available online: https://clinicaltrials.gov/ct2/ show/NCT02548559 (accessed on 19 November 2020).

168. Gruber, S.; Mclean Hospital. NTC04286594. A Clinical Trial of a Hemp-Derived Cannabidiol Product for Anxiety. Available online: https://clinicaltrials.gov/ct2/show/NCT04286594 (accessed on 19 November 2020).

169. McMaster University. NCT03549819. Cannabidiol for the Treatment of Anxiety Disorders: An 8-Week Pilot Study. Available online: https://clinicaltrials.gov/ct2/show/NCT03549819 (accessed on 19 November 2020).

170. CB2 Insights. NCT04267679. Cannabidiol for Anxiety. Available online: https://clinicaltrials.gov/ct2/show/ NCT04267679 (accessed on 19 November 2020). 
171. University of Texas at Austin. NCT04197102. Use of CBD Oil in the Treatment of Posttraumatic Stress Disorder. Available online: https:/www.clinicaltrials.gov/ct2/show/NCT04197102 (accessed on 19 November 2020).

172. National Institutes of Health (NIH). NCT03248167. Cannabidiol as a Treatment for AUD Comorbid with PTSD. Available online: https://clinicaltrials.gov/ct2/show/NCT03248167 (accessed on 19 November 2020).

173. Multidisciplinary Association for Psychedelic Studies. NCT02759185. Study of Four Different Potencies of Smoked Marijuana in 76 Veterans with PTSD. Available online: https://clinicaltrials.gov/ct2/show/ NCT02759185 (accessed on 19 November 2020).

174. Portenoy, R.K.; Ganae-Motan, E.D.; Allende, S.; Yanagihara, R.; Shaiova, L.; Weinstein, S.; McQuade, R.; Wright, S.; Fallon, M.T. Nabiximols for opioid-treated cancer patients with poorly-controlled chronic pain: A randomized, placebo-controlled, graded-dose trial. J. Pain Off. J. Am. Pain Soc. 2012, 13, 438-449. [CrossRef]

175. Corroon, J.; Phillips, J.A. A Cross-Sectional Study of Cannabidiol Users. Cannabis Cannabinoid Res. 2018, 3, 152-161. [CrossRef]

176. Federal University of Rio Grande do Sul; University of Sao Paulo. NCT03310593. Cannabidiol as an Adjunctive Treatment for Bipolar Depression. Available online: https:/clinicaltrials.gov/ct2/show/ NCT03310593 (accessed on 19 November 2020).

177. APA. Diagnostic and Statistical Manual of Mental Disorders, 5th ed.; American Psychiatric Association (APA): Washington, DC, USA, 2013.

178. Andreasen, N.C. Symptoms, signs, and diagnosis of schizophrenia. Lancet 1995, 346, 477-481. [CrossRef]

179. Laursen, T.M.; Nordentoft, M.; Mortensen, P.B. Excess early mortality in schizophrenia. Annu. Rev. Clin. Psychol. 2014, 10, 425-448. [CrossRef]

180. Kahn, R.S.; Winter van Rossum, I.; Leucht, S.; McGuire, P.; Lewis, S.W.; Leboyer, M.; Arango, C.; Dazzan, P.; Drake, R.; Heres, S.; et al. Amisulpride and olanzapine followed by open-label treatment with clozapine in first-episode schizophrenia and schizophreniform disorder (OPTiMiSE): A three-phase switching study. Lancet Psychiatry 2018, 5, 797-807. [CrossRef]

181. Maric, N.P.; Jovicic, M.J.; Mihaljevic, M.; Miljevic, C. Improving Current Treatments for Schizophrenia. Drug Dev. Res. 2016, 77, 357-367. [CrossRef] [PubMed]

182. Zuardi, A.W.; Crippa, J.A.; Hallak, J.E.; Moreira, F.A.; Guimaraes, F.S. Cannabidiol, a Cannabis sativa constituent, as an antipsychotic drug. Braz. J. Med. Biol. Res. 2006, 39, 421-429. [CrossRef] [PubMed]

183. Jones, C.A.; Watson, D.J.; Fone, K.C. Animal models of schizophrenia. Br. J. Pharmacol. 2011, 164, 1162-1194. [CrossRef]

184. Deiana, S.; Watanabe, A.; Yamasaki, Y.; Amada, N.; Kikuchi, T.; Stott, C.; Riedel, G. MK-801-induced deficits in social recognition in rats: Reversal by aripiprazole, but not olanzapine, risperidone, or cannabidiol. Behav. Pharm. 2015, 26, 748-765. [CrossRef]

185. Renard, J.; Loureiro, M.; Rosen, L.G.; Zunder, J.; de Oliveira, C.; Schmid, S.; Rushlow, W.J.; Laviolette, S.R. Cannabidiol Counteracts Amphetamine-Induced Neuronal and Behavioral Sensitization of the Mesolimbic Dopamine Pathway through a Novel mTOR/p70S6 Kinase Signaling Pathway. J. Neurosci. 2016, 36, 5160-5169. [CrossRef]

186. Gururajan, A.; Taylor, D.A.; Malone, D.T. Effect of cannabidiol in a MK-801-rodent model of aspects of schizophrenia. Behav. Brain Res. 2011, 222, 299-308. [CrossRef]

187. Gururajan, A.; Taylor, D.A.; Malone, D.T. Cannabidiol and clozapine reverse MK-801-induced deficits in social interaction and hyperactivity in Sprague-Dawley rats. J. Psychopharmacol. 2012, 26, 1317-1332. [CrossRef]

188. Osborne, A.L.; Solowij, N.; Babic, I.; Huang, X.F.; Weston-Green, K. Improved Social Interaction, Recognition and Working Memory with Cannabidiol Treatment in a Prenatal Infection (poly I:C) Rat Model. Neuropsychopharmacology 2017, 42, 1447-1457. [CrossRef]

189. Osborne, A.L.; Solowij, N.; Babic, I.; Lum, J.S.; Newell, K.A.; Huang, X.F.; Weston-Green, K. Effect of cannabidiol on endocannabinoid, glutamatergic and GABAergic signalling markers in male offspring of a maternal immune activation (poly I:C) model relevant to schizophrenia. Prog. Neuro-Psychopharmacol. Biol. Psychiatry 2019, 95, 109666. [CrossRef]

190. Jimenez Naranjo, C.; Osborne, A.L.; Weston-Green, K. Effect of cannabidiol on muscarinic neurotransmission in the pre-frontal cortex and hippocampus of the poly I:C rat model of schizophrenia. Prog. Neuro-Psychopharmacol. Biol. Psychiatry 2019, 94, 109640. [CrossRef] [PubMed] 
191. Stark, T.; Ruda-Kucerova, J.; Iannotti, F.A.; D'Addario, C.; Di Marco, R.; Pekarik, V.; Drazanova, E.; Piscitelli, F.; Bari, M.; Babinska, Z.; et al. Peripubertal cannabidiol treatment rescues behavioral and neurochemical abnormalities in the MAM model of schizophrenia. Neuropharmacology 2019, 146, 212-221. [CrossRef] [PubMed]

192. Gomes, F.V.; Issy, A.C.; Ferreira, F.R.; Viveros, M.P.; Del Bel, E.A.; Guimaraes, F.S. Cannabidiol Attenuates Sensorimotor Gating Disruption and Molecular Changes Induced by Chronic Antagonism of NMDA receptors in Mice. Int. J. Neuropsychopharmacol. Off. Sci. J. Coll. Int. Neuropsychopharmacol. 2014, 18. [CrossRef] [PubMed]

193. Gomes, F.V.; Llorente, R.; Del Bel, E.A.; Viveros, M.P.; Lopez-Gallardo, M.; Guimaraes, F.S. Decreased glial reactivity could be involved in the antipsychotic-like effect of cannabidiol. Schizophr. Res. 2015, 164, 155-163. [CrossRef]

194. Rodrigues da Silva, N.; Gomes, F.V.; Sonego, A.B.; Silva, N.R.D.; Guimaraes, F.S. Cannabidiol attenuates behavioral changes in a rodent model of schizophrenia through 5-HT1A, but not CB1 and CB2 receptors. Pharm. Res. 2020, 156, 104749. [CrossRef] [PubMed]

195. Peres, F.F.; Diana, M.C.; Suiama, M.A.; Justi, V.; Almeida, V.; Bressan, R.A.; Zuardi, A.W.; Hallak, J.E.; Crippa, J.A.; Abilio, V.C. Peripubertal treatment with cannabidiol prevents the emergence of psychosis in an animal model of schizophrenia. Schizophr. Res. 2016, 172, 220-221. [CrossRef]

196. Moreira, F.A.; Guimaraes, F.S. Cannabidiol inhibits the hyperlocomotion induced by psychotomimetic drugs in mice. Eur. J. Pharm. 2005, 512, 199-205. [CrossRef]

197. Pedrazzi, J.F.; Issy, A.C.; Gomes, F.V.; Guimaraes, F.S.; Del-Bel, E.A. Cannabidiol effects in the prepulse inhibition disruption induced by amphetamine. Psychopharmacology 2015, 232, 3057-3065. [CrossRef]

198. Long, L.E.; Malone, D.T.; Taylor, D.A. Cannabidiol reverses MK-801-induced disruption of prepulse inhibition in mice. Neuropsychopharmacology 2006, 31, 795-803. [CrossRef]

199. Long, L.E.; Chesworth, R.; Huang, X.F.; Wong, A.; Spiro, A.; McGregor, I.S.; Arnold, J.C.; Karl, T. Distinct neurobehavioural effects of cannabidiol in transmembrane domain neuregulin 1 mutant mice. PLoS ONE 2012, 7, e34129. [CrossRef]

200. Ligresti, A.; Moriello, A.S.; Starowicz, K.; Matias, I.; Pisanti, S.; De Petrocellis, L.; Laezza, C.; Portella, G.; Bifulco, M.; Di Marzo, V. Antitumor activity of plant cannabinoids with emphasis on the effect of cannabidiol on human breast carcinoma. J. Pharmacol. Exp. Ther. 2006, 318, 1375-1387. [CrossRef] [PubMed]

201. Leweke, F.M.; Piomelli, D.; Pahlisch, F.; Muhl, D.; Gerth, C.W.; Hoyer, C.; Klosterkotter, J.; Hellmich, M.; Koethe, D. Cannabidiol enhances anandamide signaling and alleviates psychotic symptoms of schizophrenia. Transl. Psychiatry 2012, 2, e94. [CrossRef] [PubMed]

202. Saletti, P.G.; Tomaz, C. Cannabidiol effects on prepulse inhibition in nonhuman primates. Rev. Neurosci. 2018, 30, 95-105. [CrossRef] [PubMed]

203. De Petrocellis, L.; Vellani, V.; Schiano-Moriello, A.; Marini, P.; Magherini, P.C.; Orlando, P.; Di Marzo, V. Plant-derived cannabinoids modulate the activity of transient receptor potential channels of ankyrin type-1 and melastatin type-8. J. Pharmacol. Exp. Ther. 2008, 325, 1007-1015. [CrossRef] [PubMed]

204. Corfas, G.; Roy, K.; Buxbaum, J.D. Neuregulin 1-erbB signaling and the molecular/cellular basis of schizophrenia. Nat. Neurosci. 2004, 7, 575-580. [CrossRef] [PubMed]

205. Kano, M.; Ohno-Shosaku, T.; Hashimotodani, Y.; Uchigashima, M.; Watanabe, M. Endocannabinoid-mediated control of synaptic transmission. Physiol. Rev. 2009, 89, 309-380. [CrossRef]

206. Bakas, T.; van Nieuwenhuijzen, P.S.; Devenish, S.O.; McGregor, I.S.; Arnold, J.C.; Chebib, M. The direct actions of cannabidiol and 2-arachidonoyl glycerol at GABAA receptors. Pharm. Res. 2017, 119, 358-370. [CrossRef]

207. Pretzsch, C.M.; Freyberg, J.; Voinescu, B.; Lythgoe, D.; Horder, J.; Mendez, M.A.; Wichers, R.; Ajram, L.; Ivin, G.; Heasman, M.; et al. Effects of cannabidiol on brain excitation and inhibition systems; a randomised placebo-controlled single dose trial during magnetic resonance spectroscopy in adults with and without autism spectrum disorder. Neuropsychopharmacology 2019, 44, 1398-1405. [CrossRef]

208. Lewis, D.A.; Levitt, P. Schizophrenia as a disorder of neurodevelopment. Annu. Rev. Neurosci. 2002, 25, 409-432. [CrossRef] 
209. Bhattacharyya, S.; Morrison, P.D.; Fusar-Poli, P.; Martin-Santos, R.; Borgwardt, S.; Winton-Brown, T.; Nosarti, C.; CM, O.C.; Seal, M.; Allen, P.; et al. Opposite effects of delta-9-tetrahydrocannabinol and cannabidiol on human brain function and psychopathology. Neuropsychopharmacology 2010, 35, 764-774. [CrossRef]

210. Devane, W.A.; Hanus, L.; Breuer, A.; Pertwee, R.G.; Stevenson, L.A.; Griffin, G.; Gibson, D.; Mandelbaum, A.; Etinger, A.; Mechoulam, R. Isolation and structure of a brain constituent that binds to the cannabinoid receptor. Science 1992, 258, 1946-1949. [CrossRef] [PubMed]

211. Petitet, F.; Jeantaud, B.; Reibaud, M.; Imperato, A.; Dubroeucq, M.C. Complex pharmacology of natural cannabinoids: Evidence for partial agonist activity of delta9-tetrahydrocannabinol and antagonist activity of cannabidiol on rat brain cannabinoid receptors. Life Sci. 1998, 63, PL1-PL6. [CrossRef]

212. Boggs, D.L.; Nguyen, J.D.; Morgenson, D.; Taffe, M.A.; Ranganathan, M. Clinical and Preclinical Evidence for Functional Interactions of Cannabidiol and Delta(9)-Tetrahydrocannabinol. Neuropsychopharmacology 2018, 43, 142-154. [CrossRef] [PubMed]

213. Bioque, M.; Garcia-Bueno, B.; Macdowell, K.S.; Meseguer, A.; Saiz, P.A.; Parellada, M.; Gonzalez-Pinto, A.; Rodriguez-Jimenez, R.; Lobo, A.; Leza, J.C.; et al. Peripheral endocannabinoid system dysregulation in first-episode psychosis. Neuropsychopharmacology 2013, 38, 2568-2577. [CrossRef]

214. De Marchi, N.; De Petrocellis, L.; Orlando, P.; Daniele, F.; Fezza, F.; Di Marzo, V. Endocannabinoid signalling in the blood of patients with schizophrenia. Lipids Health Dis. 2003, 2, 5. [CrossRef]

215. Zuardi, A.W.; Crippa, J.A.; Hallak, J.E.; Pinto, J.P.; Chagas, M.H.; Rodrigues, G.G.; Dursun, S.M.; Tumas, V. Cannabidiol for the treatment of psychosis in Parkinson's disease. J. Psychopharmacol. 2009, 23, 979-983. [CrossRef]

216. Zuardi, A.W.; Rodrigues, J.A.; Cunha, J.M. Effects of cannabidiol in animal models predictive of antipsychotic activity. Psychopharmacology 1991, 104, 260-264. [CrossRef]

217. Boggs, D.L.; Surti, T.; Gupta, A.; Gupta, S.; Niciu, M.; Pittman, B.; Schnakenberg Martin, A.M.; Thurnauer, H.; Davies, A.; D'Souza, D.C.; et al. The effects of cannabidiol (CBD) on cognition and symptoms in outpatients with chronic schizophrenia a randomized placebo controlled trial. Psychopharmacology 2018, 235, 1923-1932. [CrossRef]

218. McGuire, P.; Robson, P.; Cubala, W.J.; Vasile, D.; Morrison, P.D.; Barron, R.; Taylor, A.; Wright, S. Cannabidiol (CBD) as an Adjunctive Therapy in Schizophrenia: A Multicenter Randomized Controlled Trial. Am. J. Psychiatry 2018, 175, 225-231. [CrossRef]

219. O’Neill, A.; Wilson, R.; Blest-Hopley, G.; Annibale, L.; Colizzi, M.; Brammer, M.; Giampietro, V.; Bhattacharyya, S. Normalization of mediotemporal and prefrontal activity, and mediotemporal-striatal connectivity, may underlie antipsychotic effects of cannabidiol in psychosis. Psychol. Med. 2020, 1-11. [CrossRef]

220. Bhattacharyya, S.; Wilson, R.; Appiah-Kusi, E.; O’Neill, A.; Brammer, M.; Perez, J.; Murray, R.; Allen, P.; Bossong, M.G.; McGuire, P. Effect of Cannabidiol on Medial Temporal, Midbrain, and Striatal Dysfunction in People at Clinical High Risk of Psychosis: A Randomized Clinical Trial. JAMA Psychiatry 2018, 75, 1107-1117. [CrossRef] [PubMed]

221. Wilson, R.; Bossong, M.G.; Appiah-Kusi, E.; Petros, N.; Brammer, M.; Perez, J.; Allen, P.; McGuire, P.; Bhattacharyya, S. Cannabidiol attenuates insular dysfunction during motivational salience processing in subjects at clinical high risk for psychosis. Transl. Psychiatry 2019, 9, 203. [CrossRef] [PubMed]

222. Hallak, J.E.; Machado-de-Sousa, J.P.; Crippa, J.A.; Sanches, R.F.; Trzesniak, C.; Chaves, C.; Bernardo, S.A.; Regalo, S.C.; Zuardi, A.W. Performance of schizophrenic patients in the Stroop Color Word Test and electrodermal responsiveness after acute administration of cannabidiol (CBD). Braz. J. Psychiatry 2010, 32, 56-61. [CrossRef] [PubMed]

223. Sheppard Pratt Health System; University of California, Los Angeles. NTC03883360. Effects of Cannabidiol on Psychiatric Symptons, Cognition, and Cannabis Consumption in Cannabis Users with Recent-Onset Psychosis. Available online: https://clinicaltrials.gov/ct2/show/NCT03883360 (accessed on 19 November 2020).

224. Central Institute of Mental Health, Mannheim. NCT02926859. Enhancing Recovery in Early Schizophrenia. Available online: https://clinicaltrials.gov/ct2/show/NCT02926859 (accessed on 19 November 2020).

225. Cadenhead, K.; University of California, San Diego. NCT04411225. Center for Medicinal Cannabis Research. Effects of cannabidiol (CBD) versus Placebo as an Adjunct to Treatment in Early Psychosis. Available online: https://clinicaltrials.gov/ct2/show/NCT04411225 (accessed on 19 November 2020). 
226. Elsaid, S.; Kloiber, S.; Le Foll, B. Effects of cannabidiol (CBD) in neuropsychiatric disorders: A review of pre-clinical and clinical findings. Prog. Mol. Biol. Transl. Sci. 2019, 167, 25-75. [CrossRef]

227. Shi, Q.X.; Yang, L.K.; Shi, W.L.; Wang, L.; Zhou, S.M.; Guan, S.Y.; Zhao, M.G.; Yang, Q. The novel cannabinoid receptor GPR55 mediates anxiolytic-like effects in the medial orbital cortex of mice with acute stress. Mol. Brain 2017, 10, 38. [CrossRef]

228. Rahimi, A.; Moghaddam, A.H.; Roohbakhsh, A. Central administration of GPR55 receptor agonist and antagonist modulates anxiety-related behaviors in rats. Fundam. Clin. Pharm. 2015, 29, 185-190. [CrossRef]

Publisher's Note: MDPI stays neutral with regard to jurisdictional claims in published maps and institutional affiliations.

(C) 2020 by the authors. Licensee MDPI, Basel, Switzerland. This article is an open access article distributed under the terms and conditions of the Creative Commons Attribution (CC BY) license (http://creativecommons.org/licenses/by/4.0/). 